

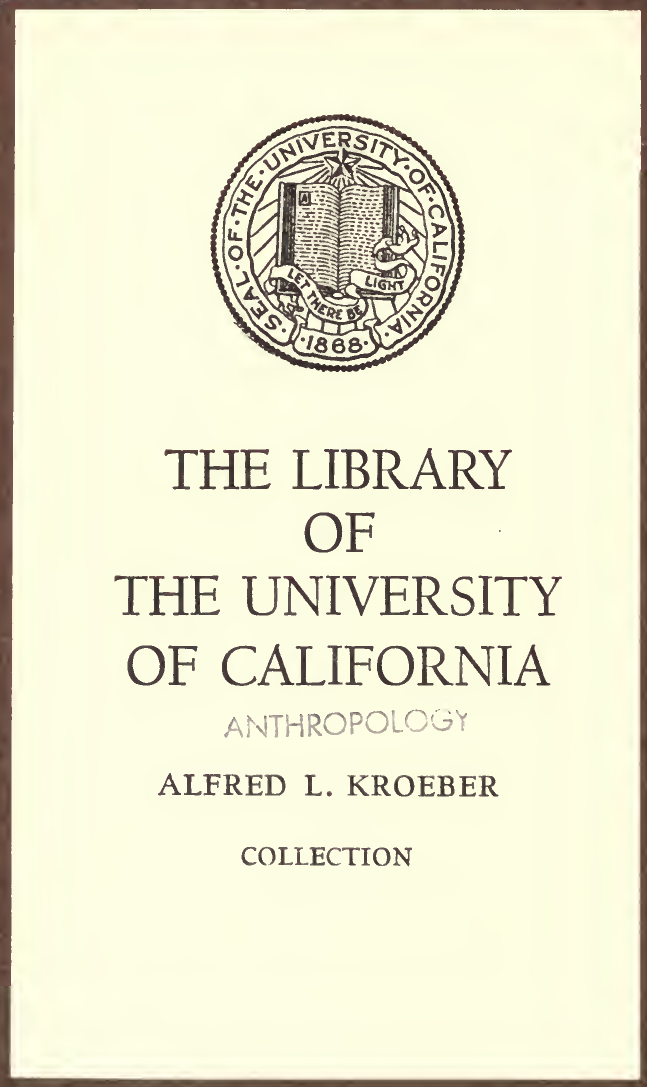


1)

II 



\section{SMITHSONIAN MISCELLANEOUS COLLECTIONS}

VOLUME 70, NUMBER 3

\section{ARCHEOLOGICAL INVESTIGATIONS AT PARAGONAH, UTAH}

(With Fifteen Plates)

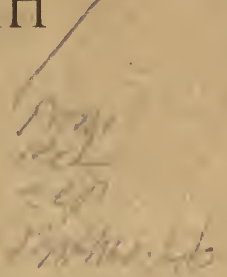

BY

NEIL, M. JUUDD,

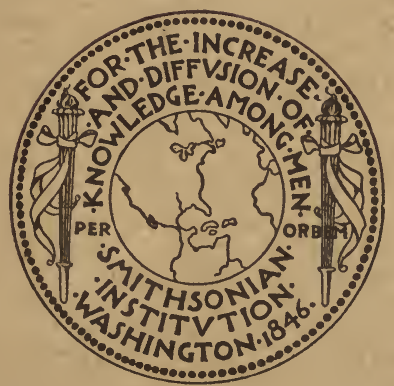

(Publication 2536)

GITY OF WASHINGTON DOCUMENTS DEPANTMEIT OCT उ 13501 PUBLISHED BY THE SMITHSONIAN INSTITUTION OF CALIFOEKLA 1919 
SMITHSONIAN MISCELLANEOUS COLLECTIONS VOLUME 70, NUMBER 3

\section{ARCHEOLOGICAL INVESTIGATIONS AT PARAGONAH, UTAH}

(With Fifteen Plates)

BY

NEIL M. JUDD

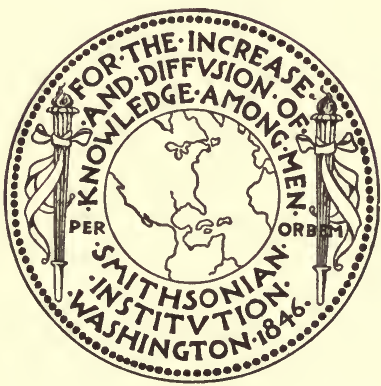

(Publication 2536)
DOCUMENTS DEPARTMENT

OCT 311961

LBRARY

UNIVERSITY OF GALIFORNIA

GITY OF WASHINGTON

PUBLISHED BY THE SMITHSONIAN INSTITUTION 
Ebe Rord Gaftimore ppreas

BALTIMORE, ME., $\sigma$. S. A. 


\section{ARCHEOLOGICAL INVESTIGATIONS AT PARAGONAH, UTAH \\ By NEIL M. JUDD \\ (With Fifteen Plates)}

\section{INTRODUCTION}

The remains of ancient habitations now visible near Paragonah in Iron County, Utah, comprise but a small remnant of the total number which formerly overlooked the broad Parowan Valley, from the foothills between Red and Little Creek canyons. It is recorded ${ }^{2}$ that Dr. H. C. Yarrow, of the Wheeler Survey, observed more than 400 mounds in this vicinity in 1872 . The figure given, in itself, suggests a possible exaggeration and yet many ruins were unquestionably razed during the succeeding 20 years as the cultivated fields of the modern community increased in extent. Prof. Henry Montgomery, then of the University of Utah, reports ${ }^{2}$ approximately Ioo mounds near Paragonah in I893 and a like estimate is given by Mr. Don Maguire of Ogden, Utah, who conducted excavations at the same time as Professor Montgomery in the interest of the Chicago World's Fair. Less than half of these remained in 19r5, when the writer began his investigations for the Bureau of American Ethnology and the number was still further reduced during the next I2 months, leaving a bare half-dozen large elevations in the fields already under cultivation and several smaller mounds in the sagecovered area adjoining. But the largest of these, whose size alone has delayed their reduction, had also attracted earlier investigators and each mound still bears the scars of their several undertakings.

In addition to the above observers Dr. Edward Palmer, of the U. S. National Museum, conducted limited excavations at the same locality during one of his numerous expeditions through southwestern Utah between I869 and I877. None of these investigators, however, with the single exception of Professor Montgomery, ${ }^{8}$ has published an

\footnotetext{
${ }^{1}$ U. S. Geographical Surveys West of the Iooth Meridian, Capt. G. M. Wheeler, Vol. I, p. 57. Washington, D. C., I889.

${ }^{2}$ The Archaeologist, Vol. 2, p. 303, I894.

${ }^{3}$ Ibid., pp. 303-306.
} 
account of his researches. The writer's own impressions, gained in 1915 and 1916 , have been, as yet, but partially recorded, ${ }^{1}$ a more detailed report being withheld pending completion of additional investigations. It is obvious, therefore, that the remains of an unusually large number of prehistoric dwellings near the village above mentioned have gradually given way before the advance of agricultural preference and that, notwithstanding the many observations made among them, the ruins have contributed but little to our scanty knowledge of their ancient inhabitants and have left us with only the vaguest understanding of the degree of culture to which their builders had attained.

The present paper finds its origin in a joint expedition undertaken in 1917 by the Smithsonian Institution and the University of Utah, at the request of the latter. The writer had the honor and the pleasure of directing the work, with the cordial cooperation of President John A. Widtsoe and Prof. Levi Edgar Young, of the university, ${ }^{2}$ and with the active assistance of Mr. Andrew A. Kerr as their field representative.

It must be confessed that, for the layman, there is but little of the spectacular in the results of the expedition. The student of history, on the other hand, will find much to hold his attention-rude dwellings of earth that seem so thoroughly adapted to their environment and vast quantities of minor antiquities, each of which is its own key to the daily activities and industries of the ancient house builders. Here was a people who came from some distant, undetermined region-a people that established a compact community, with a definite social organization, and then passed on to a new locality where another cycle in their tribal history was unfolded. Innumerable paragraphs might be written from the information at hand and yet,

\footnotetext{
${ }^{1}$ Smithsonian Misc. Coll., Vol. 66, No. 3, p. 67 ; No. I7, pp. 103-107.

${ }^{2}$ It should be stated that the successful inauguration and furtherance of the season's unclertaking was due largely to the interest and perseverance of President Widtsoe and Professor Young. They first enlisted the aid of the government institution and, thereafter, freely rendered every possible assistance in bringing the work of the expedition to a happy conclusion.

In this place, also, the writer desires to acknowledge his appreciation of the generous spirit in which his numerous Paragonah friends contributed to the success of the expedition and he is especially indebted to Mrs. Martha Jane Openshaw and Mr. Isaac Bozarth who kindly granted the necessary permission to conduct the excavations. The ultimate purpose of science can always be best served by such whole-hearted good will and mutual helpfulness as that which greeted the 1917 party.
} 
at this time, it seems unwise to attempt more than a general survey of the season's discoveries, reserving for a subsequent paper the tempting comparison between the cultural evidence disclosed at Paragonah and that found among ancient ruins in other sections of the Southwest. Likewise, direct reference to previous investigations of the Smithsonian Institution in Parowan and neighboring valleys will be avoided in so far as possible, that the following pages may be devoted entirely to the joint enterprise of I9I7. A certain heterogeneity frequently obtains among archeological remains in western Utah-such a confusion and intermingling of like and unlike structures that the entire subject may be explained most clearly in a monograph based upon knowledge gained throughout the vast region in which similar remains occur. The present paper treats of but one small section of that region and the results of I9I7 should be considered merely as a single, though highly important, contribution toward final solution of the whole complex question.

\section{EXCAVATION OF THE BIG MOUND}

Paragonah was reached early in July and the party at once centered its attention upon an elevation known locally as " the big mound," a huge knoll measuring approximately 225 feet in diameter and Io feet high. There were several reasons for this selection: (I) It was the largest of those remaining and, notwithstanding the previous removal of the southern one-third and superficial evidence of other excavations, it still promised more perfect examples of architecture and deeper court deposits than adjacent mounds; (2) being in the way of proposed improvements, it was in imminent danger of complete reduction, with final loss of its archeologic contents ; and (3) exposure of the house-group which the "big mound" was thought to cover would form a fitting sequel to earlier studies of smaller elevations containing from one to five dwellings, together with their related structures.

The ragged blanket of sage-brush which covered the mound was first cut and burned. Trenches were then begun in several places, in search of walls, floors, etc. The actual work of excavation was done with shovels ; teams and scrapers being employed only in removing the earth which had been examined and thrown out by the workmen. This method, although slower, resulted in more extensive collections of small artifacts and insured, also, greater accuracy in tracing the various floor levels and house walls, some of which were determined only with the greatest difficulty owing to their coloration 
and to the compact condition of the surrounding soil. When house remains were encountered they were immediately exposed, provided no connecting structures were discovered which required previous attention. Working from one dwelling to another, the entire series was finally uncovered.

Early in the course of the excavations it became evident that in the "big mound," as in other similar elevations, ruins of two distinct types were to be found. These naturally increased in numbers as the work progressed, but the obvious relationship between the two types did not differ materially from that established during former operations. The chief task of the I9I7 expedition, therefore, soon resolved itself into an effort to locate all of the more permanent houses and to discover in the lesser structures invariably associated with them any variation from their customary form. The outstanding features of each type are given below, with additional notes on certain individual ruins.

In general, every prehistoric community attracts the student both through its architecture and its lesser antiquities, for the house remains, perhaps more completely than the artifacts found within or near them, furnish a true index to the cultural attainments of their builders. And it is the degree of social and material advancement, as evidenced by such remains and by such artifacts, that enables the anthropologist to assign to any given people its approximate place on the ladder of intellectual progress. In considering the results of excavations in the big mound at Paragonah, therefore, attention will first be directed to the structures occupied by the aborigines and then to the minor objects discovered in connection with those structures.

\section{HOUSE REMAINS}

Reference to the ground plan (pl. I) of the mound under consideration shows a number of adjacent, rectangular rooms and several additional buildings. It will be noticed, also, that some of these rooms appear one above the other, but, even in such instances, there is evidence of a purposeful arrangement and the constant recognition of a previously determined relationship. The fireplaces in the areas contiguous to the rectangular rooms indicate the location of temporary structures, occupied in conjunction with the more permanent buildings. All the fireplaces discovered during the course of the excavations are not shown on the ground plan, for they were found indiscriminately and throughout the entire depth of the mound in such numbers as to render impracticable their proper delineation. 
The walls of the quadrangular buildings were constructed entirely of adobe, usually in layers, and averaging about ro inches in thickness. No complete wall has yet been found, but it is reasonable to suppose that none of these exceeded in height the walls of other prehistoric habitations throughout the Southwest, that is to say, from $4 \frac{1}{2}$ to 5 feet. This does not mean, however, that the inhabitants were of small stature, a fallacy which has an unfortunately wide circulation. Small houses were easier to build and they afforded greater protection from the elements; they were utilized primarily as sleeping quarters and for the storage of corn, beans, and other foodstuffs. They were designed chiefly to meet these requirements; the daily activities of their owners being performed mostly out of doors or in the shelter of secondary structures.

Much has been said regarding the manner in which these adobe dwellings were constructed, but it has been pointed out elsewhere ${ }^{1}$ that the methods employed were not so complex as has been commonly supposed. The builders required merely an abundant watersupply and the clayey soil of the region. A shallow hole near the site of the proposed house sufficed as a mixing box, into which water was poured as needed; the hole grew in extent and depth as its sides were cut down to furnish additional clay. This was undoubtedly mixed by the bare feet of the workers, a method still employed by modern Pueblo Indians and their Mexican neighbors.

Balls of this mud, worked to a stiff paste, were then thrown on to a prepared area, tracing the outline of the room. Other masses were added and the four walls gradually assumed their desired height. Of necessity these were built up in layers, for the cohesive properties of plastic clay are very low and supporting forms were unknown among the primitive peoples of America. Each layer averaged about ${ }_{5} 5$ inches in thickness and the desert sun soon dried it sufficiently to permit of the addition of a superposed course. The fact that these layers vary in thickness from a few inches to more than a foot may be traced usually to an effort on the part of the builders to maintain uniform levels-an unintentional irregularity in one layer would be corrected in placing the next above it. Mud plaster was ordinarily employed in smoothing the inner faces of these walls, but it is sometimes apparent that the freshly laid adobe was merely dampened with water and surfaced over, obliterating all traces of joints.

\footnotetext{
${ }^{1}$ Judd in Holmes Anniversary Volume, pp. 24I-252. Washington, D. C., I9I6.
} 
Working in this way, using their bare hands and with no tools other than crude bone and stone implements, the ancient artisans finally brought the new walls to a satisfactory height. A number of wooden beams were then laid a foot or more apart and across the shorter dimensions of the room; above and at right angles to them, smaller poles were placed, with willows or brush, grass and clay, in succession, completing the roof. The resulting cover was fairly tight, but extremely heavy ; it successfully turned most of the winter's storms and required repair only two or three times a year, following the rainy seasons. Windows for the admission of light and air were unknown-aboriginal peoples seldom worried about ventilation or lack of it-and the only entrance to the room was a hole through the roof, an opening which was closed at times by a large, thin stone disk. ${ }^{1}$

The primitive masons of Parowan Valley had adapted to their needs the most available building material of their environment; they constructed houses which met their principal requirements and yet these houses had at least one defect which their builders seem not to have overcome. It is apparent that the roof beams did not protrude far beyond the outer surface of the sun-dried mud walls and consequently furnished scant protection for them. In seasons of rainfall, the water which accumulated upon the flat earthen roof either soaked through or ran off the edges and down the walls. In the latter case, the softened adobe would tend to give way under the weight of the heavy ceiling, causing the walls to collapse. It may safely be assumed that these dwellings were frequently destroyed in this manner, even though the opinion be based entirely upon circumstantial evidence, for many travelers in the Southwest have noticed the disintegration of modern adobe houses through the same agency.

A dwelling once destroyed was probably never wholly rebuilt, although its broken walls may have been partially utilized in the erection of a new structure. Lack of suitable tools made the mere task of removing such wreckage a tedious undertaking. To obviate the necessity for this and yet render the site suitable for a new

\footnotetext{
${ }^{1}$ The writer has been informed through several sources that the stone employed in making the round doors found so frequently among the Paragonah ruins could have come only from the West Mountains or Kane Spring Hills, Io miles from the village. Stone of similar texture is unknown elsewhere in the vicinity; the difficulties of its transportation may be appreciated if the reader will recall that these old people had no beasts of burden and that many of the disks weigh as much as 75 and 80 pounds.
} 
habitation, the old walls were pulled down upon themselves, the mass brought to a uniform level, and erection of the substitute structure begun.

In a previous paper, ${ }^{1}$ the present writer has briefly described the occurrence of superposed dwellings in mounds excavated at Beaver City, Utah. They, like the ones now under discussion, did not always possess the same floor area as the buildings they replaced. In some instances, one or more walls of the upper house coincided with those of the lower; in others, the long axis of the later dwelling lay at right angles to that of the earlier. The mere position of the new habitation seemingly did not influence its builders so much as the fact that necessity compelled its erection and that preference or social custom influenced its construction on the site of the one destroyed.

The occasional superposition of dwellings adds greatly to the interest of such structures as those disclosed by the I9I7 excavations. A few of them, briefly described, may serve not only to indicate the general problems involved, but they may also contribute, in a greater or less degree, to an understanding of their primitive builders. Rooms I6-I9, for example, occur in three distinct levels. Numbers I6 and I7 originally comprised a single room, but this was subsequently divided by a partition only half as thick as the main walls. Still later, both houses appear to have been abandoned, although Room I7 may have been temporarily occupied after construction of the neighboring house, number I8. A continuation of the floor level of this latter dwelling extended out over the razed walls of Room I6, 2 feet 9 inches above their inner base.

The length of the upper structure was nearly as great as that of Rooms I6 and I7 combined; the condition of its floor suggests occupancy during a considerable period. For some unknown reason, however, the walls of number 18 were later demolished and Room I9, a building only half as long, was erected above them. Seventeen inches of closely packed building material separated the two floors; the width of the structures was approximately the same, although the walls of the one did not rest directly upon those of the other.

The neighboring houses, numbers 8 to 12 , furnish a similar example of superposition. Rooms 9 and I I were built above the partially razed walls of Rooms 8, I0, and I2. Number 8 was constructed subsequently to Room Io, its floor being approximately io inches

\footnotetext{
${ }^{1}$ Proceedings of the Nineteenth International Congress of Americanists, pp. II9-124. Washington, D. C., I9I7.
} 
above that of the latter; Room 12 was erected at the same time and on the same level as Room Io.

The walls of all three first-level houses were entirely of adobe, built up in layers, and smoothed or plastered on the inside. There is no means of determining the length of time each was inhabited, but, after a certain period of occupancy, they gave way to Rooms 9 and II. Here again the walls of the upper structures do not coincide exactly with those of the lower; their orientation, nevertheless, remains practically the same. The floors in Rooms 9 and I I had been constructed 3 feet 9 inches above that in number Io and rested directly upon the irregular chunks of sun-dried adobe which formerly composed the walls of the lower room. Plate 3 illustrates the relationship between the outer west walls of Rooms 8 and 9 and shows the difference in their respective floor levels.

While considering this series of dwellings, attention should be called to certain peculiarities which have not been observed during the excavation of other similar houses. In the outer east wall of Room 8, averaging 36 inches above its base and I 2 inches apart, was a row of small holes, marking the former position of as many wall pegs or hangers; additional pegs may have existed in the destroyed portion of the same wall. Holes of this sort in adobe dwellings are really unique; owing to their low position the use to which they were put must remain doubtful. A doorway, I7 inches wide and about 24 inches high, pierced the south wall of this room, it being the only lateral entrance yet observed among the prehistoric adobe dwellings of western Utah. So far as could be determined neither wood nor stone had been utilized in its frame. Room 9, directly above this house, was obviously entered through the customary roof opening.

At the south end of Room IO, in its opposite walls and 20 inches above the floor, were two series of four holes each. Those on the west side averaged II inches and those on the east 4 inches from each other. They marked the former position of horizontal poles, built into the walls at the time of their construction and probably formed a rude triangular bunk or shelf. This feature, also, is believed to be unique among prehistoric ruins north and west of the Rio Colorado and, if the conjecture be correct, it represents one of the few examples of built-in benches yet discovered among aboriginal dwellings of the Southwest. Similar series of pole rests were not detected in any of the other Paragonah structures.

Room 3I, a third-level house, almost entirely destroyed by earlier excavations, was the only dwelling in the big mound whose floor 
consisted of a layer of coarse gravel and water-worn cobblestones, overlaid with adobe mud. Foundations of this character were invariably employed in the houses examined near Beaver City, Deseret and Hinckley, and they occurred frequently in those near Fillmore and Meadow, in Millard County. Excepting this course of small stones underneath the floor the house did not differ from the adobe dwellings described above.

It is to be regretted, of course, that the south one-third of the big mound had been completely razed before the recent expedition began its work. According to local reports, house walls were observed in this position of the elevation, and there are those who insist that circular rooms were also present. The number of these and the number of rectangular dwellings must always remain a matter of speculation; that they were many may be inferred from the total discovered in the remainder of the mound.

\section{ASSOCIATED STRUCTURES}

Most observers who have conducted investigations among the mounds of western Utah have noticed the occurrence of lesser structures in the areas immediately surrounding the adobe dwellings. Too little importance has been attached to these remains and their true import seems to have been generally overlooked. ${ }^{1}$ The recent excavations at Paragonah disclosed houses of this type in large numbers and it is desired at this time to refer to them, collectively, in order that their real place in the community may be fully understood. ${ }^{2}$

It will be noticed that the more permanent habitations in the big mound are grouped to form, roughly, three sides of a square. The interior of this square was filled with accumulations of camp débris and wind-blown earth, averaging 6 feet in depth. The remains of temporary shelters were found without any semblance of order

\footnotetext{
${ }^{1}$ In the papers cited above, the present writer made no attempt to elaborate upon the court shelters or their obvious bearing upon the more permanent structures. There is evidence pointing to the fact that the former are older, structurally, than the latter.

${ }^{2}$ It should be stated that plate I shows but very few of the lesser structures exposed during the excavations of 1917. They were found in such unexpected numbers and so hopelessly interlocked that it was deemed inadvisable to interrupt the main work while each one was carefully uncovered. The chief characteristics of the type had been determined by the expeditions of I9I5 and I9I6; equally cautious dissection of the "big mound" did not appear commensurate with the time and expense involved.
} 
throughout these deposits. In one place, above fireplace L, seven distinct levels of occupancy were noted and the layers which supported them frequently merged one into another or disappeared entirely a short distance from the limits of the hut. Careful analysis of these levels and the material separating them leaves the impression that the lesser structures were so easily constructed that their abandonment was effected without great compunction, once their usefulness had ended.

The charred ends of upright posts show that a large proportion of these shelters were destroyed by fire; others may have become so filled with débris and dust that their builders found it desirable to select other quarters. In the latter case, the old hut would have been pulled down and its timbers utilized in the new structure, leaving the other materials which united in its construction as a further addition to the court deposits. All this is apparent from close examination of the remains, but many of the fireplaces, unlike those exposed by previous expeditions, exhibited no trace of a former covering and it may be that they were entirely unroofed. The huts varied somewhat in size and interior arrangement, but they were of the same general type and they served a common purpose.

In their simplest form these associated structures consisted of a roof supported by four uprights and they, in turn, surrounded a circular fireplace. The posts upheld crosspieces and against them, leaning outward toward the ground, was a succession of small poles. It seems most likely that grass and eath covered these sloping timbers, enclosing the room on at least three sides. That portion of the roof lying directly above the firepit was flat and constructed in much the same manner as that of an adobe dwelling, with possible provision for a smoke vent. In ruins of these huts chunks of burned clay, bearing impressions of the several materials which composed the roof, are almost always present upon the fireplace and within the area bordered by the uprights.

These lesser structures were really the living quarters of the ancient people, rooms in which their daily activities were performed. As each family possessed one or more adobe houses-places of protection or for the storage of semi-precious possessions-so, also, did each lay claim to at least one court shelter, an associated structure in which the family cooking was done, where garments and household utensils were prepared and where all those numerous small tasks that occupied the time even of primitive folk were performed. Some such shelters possessed a second fireplace; some a shallow, basin-like 
depression near the firepit in which clean sand was kept. Some huts were larger than others; some show longer occupancy; but none is without evidence of its true use, since small implements of bone and stone, charred corn and squash seeds, potsherds, split animal bones, and other camp-fire refuse, may always be found upon the smooth earthen floors and throughout the accumulations which separate the successive levels.

Excavation of the big mound disclosed ruins of still another type, structures not previously noted among the archeological remains of western Utah. Houses of this class possess certain features found, respectively, in the rectangular adobe dwellings and in the adjacent court shelters; they represent, perhaps, attempts to provide the roominess and stability of the former while utilizing methods peculiar to the latter. Rooms 20,39, 40,4I, etc., are houses of the type under consideration and they are classed as secondary structures, since they apparently have a closer economic relationship to the shelters than to the heavy-walled buildings.

The first of these, although smaller than the others, may be considered typical of all. As discovered, it consisted only of a muchused floor whose outer limits were marked by a series of small postholes. A rimmed fireplace, $\mathrm{I} 3$ inches in diameter and 6 inches deep, had been cut into the floor near the south wall. It would appear that this house had been erected some time subsequent to Kiva $V$, for example, since several inches of court accumulations, including two ill-defined levels of occupancy, separated the floors of the two structures. ${ }^{1}$

Room 39 was the largest house of this type, and it, in turn, had been built 14 inches above the floor of an earlier structure of the same kind, Room 40. A rimmed fireplace, 38 inches in diameter and 4 inches deep, occupied the middle of the room, and surrounding it, as in the smaller court shelters, were four large roof supports. The walls of this building were constructed of small upright posts, wattled with brush or willows and plastered with mud. More than 30 supports had been utilized in the west wall-the holes they once occupied were only a few inches apart and nearly every one was filled with decayed wood. In part of the east wall, against Room 35, horizontal willows had been bound to the uprights before they were

\footnotetext{
${ }^{1}$ Four feet four inches above number 20 and at right angles to its long axis was a third-level dwelling, Room 2r. Its walls were entirely of adobe, constructed in the manner previously outlined; its floor was hard and smooth and rested directly upon the refuse and loose earth which covered Room 20.
} 
plastered; in another place it was determined with certainty that masses of plastic adobe had been forced between the posts and smoothed over so as to cover them.

Structures of this type, like the smaller shelters, were essentially living quarters or work rooms. Such use is indicated by the central fireplace-fireplaces were not present in any of the rectangular dwellings - and by the small objects found in the débris surrounding it. The two types were designed for similar purposes and, fundamentally, they were alike in construction. Only in form and size did they differ to any marked extent. The central roof of each was supported by four pillars; small poles made up the walls of both. In the smaller shelters these poles slanted downward and outward from crosspieces which rested upon the uprights; in the larger rooms they were set vertically and the wall supported the outer edges of a flat roof, laid in continuation of that directly above the fireplace. Structures of the first type were round or nearly so; those of the second class were quadrilateral.

\section{CEREMONIAL ROOMS}

Among the structures concealed by the big mound were three circular rooms and the remains of possibly two others. In form and in their position relative to the adjacent, rectangular dwellings these round rooms may be likened to the ceremonial chambers, or kivas, so inseparably connected with prehistoric Pueblo dwellings throughout the Southwest. They lack some of the structural details of the latter, but their use was so obviously the same that it seems permissible to employ the recognized Hopi term in referring to them. Such application of the word " kiva" has, in fact, already been made ${ }^{1}$ by the present writer, in considering circular rooms observed previously at Paragonah and in other sections of western Utah.

In all distinctly Pueblo villages, both ancient and modern, the ceremonial room was the nucleus about which the life of the community revolved; the presence of more than one kiva denoted, merely, that the village was composed of several clans, each having its own unit organization and its own center of social and religious activity. In certain historical Pueblo settlements of New Mexico and Arizona, where Spanish influence was most pronounced, ceremonial rooms lost their original shape when their builders purposely hid them among dwellings of the house cluster, as a means of forestalling priestly opposition. In other existing communities the kiva

\footnotetext{
${ }^{1}$ American Anthropologist, Vol. I9, No. I, Jan.-March, I9I7.
} 
retained its circular form, remaining somewhat isolated and wholly or partly underground. Pueblo mythology prescribed a subterranean position, in respect to habitations, for purely ceremonial rooms and the Indians of to-day still adhere to tribal custom as far as possible, despite persistent efforts of their conquerors to substitute new religious precepts for the ancient beliefs.

The kivas in the big mound at Paragonah were circular in form; they were entered through a roof opening at a level corresponding to that of the court. This subterranean, or semi-subterranean position, however, appears to have been obtained in a manner somewhat different from that which governed the construction of such rooms in cliff-dwellings and exposed pueblos. In the two latter a location already lower than the houses was frequently chosen or a natural concavity was enlarged and deepened to meet requirements, or dwellings were even built up around the kiva, leaving it in a subjacent position. The circular rooms in the big mound, on the other hand, apparently were excavated from extensive piles of débrisaccumulations which permitted the desired subterranean situation and yet left the kiva floors on practically the same level as those of the neighboring secular structures. Whether these piles were wholly artificial or whether they represented merely the usual court deposits could not be determined with certainty by the investigations of 1917 . The important fact to be considered is that circular structures have been found in this section of the west and that they were given an underground position in respect to the adobe habitations.

Architecturally, the Paragonah kivas were constructed in a very simple manner. A hole of the desired depth and diameter was excavated from accumulations of earth and camp-fire débris; its walls and floor were then surfaced with mud and allowed to dry. This method appears in sharp contrast to that employed in the adjacent houses where superposed courses were laid with considerable care. In most cliff villages of the Southwest those rooms designed primarily for ceremonial purposes represent the highest local development in masonry, but at Paragonah the contrary is true. The mud plaster was spread directly upon the face of the cut and, from the outside, there is nothing which would suggest the presence of a wall. A roof of the type previously described covered the room and the customary hatchway served as the sole means of entrance. In none of these chambers was anything found which would correspond to the sipapu, the fire screen or the wall recesses in prehistoric kivas throughout the San Juan drainage, for example. 
Among the circular rooms in the big mound, number I is especially noteworthy. As in certain habitations, it illustrates the readiness with which its ancient builders abandoned one building in favor of another or the apparent ease with which they utilized the remains of one structure in erecting a second. Kiva I may be considered as merely the contraction of a larger, similar room whose floor and north wall were retained as part of the later building; it seems a confession on the part of its builders that they lacked the skill necessary to construct successfully so large a structure as that which it replaced. When exposed the walls of the smaller room were practically intact; those of the larger had disappeared except on the north and west sides. The precursor of number I had been excavated from the loose court deposits and its walls consisted only of thick coats of mud spread directly upon the ash-bearing earth; the smaller room had been built within the larger, its north wall coinciding with that of the latter and its other sides being formed by the débris thrown upon the floor and within the razed walls of the earlier structure. A rimmed fire-place 26 inches in diameter and 3 inches deep occupied the middle of the floor. ${ }^{1}$

Kivas II and III are really counterparts of number I, although differing somewhat in size. The third of these, unfortunately mutilated during the removal of the south end of the mound, had also undergone repairs, a second floor having been laid 2 inches above the first. The room is still further unique in possessing an extra fireplace, adjoining and but slightly smaller than the usual central hearth. Against the southwest wall was a posthole which held a support for one of the heavy roof beams, a feature also noted in kivas exposed during the expeditions of I9I5 and I9I6.

The curved wall fragments of possibly two additional kivas were observed, respectively, within Room 35 and in the open court east of Rooms 8 to I2. The first of these measured only a few feet in length; its floor, although broken and so near the surface as to render its exposure difficult, was traced beyond the razed east wall of Room 35. This room was circular in form and there seems but little doubt that it was used chiefly for ceremonial purposes." Greater uncer-

\footnotetext{
${ }^{1}$ In the court accumulations between Kiva I and Rooms 8 and 32 several levels of occupancy, from 2 to ro inches in thickness, were noted. Each of these showed fireplaces and the remains of shelters associated with the neighboring rectangular habitations, but the ground plan does not presume to delineate all of those discovered.

"The necklace of bone pendants and "gaming counters" noted on page 16 was found on the floor of this room.
} 
tainty exists regarding the other room, which has been marked Kiva V. Its floor lay in that portion of the mound where superposed levels of occupancy were most numerous, and it may be that the room was no more than an enlarged shelter. Fragments of curved adobe walls remained on the eastern side and these, if continued, would have circled a central fireplace about which four large pillars formerly stood. It is the presence of these surrounding posts that suggests the possibility of this having been one of the numerous associated structures, but kivas with roofs supported by uprights were noted, also, during preceding expeditions and in so large a room pillars would have been absolutely necessary. Curved adobe walls, on the other hand, have not yet been observed among the remains of purely court shelters.

\section{MINOR ANTIQUITIES}

In reviewing the minor antiquities exposed during the excavation of the "big mound" the observer will, first of all, be attracted by the preponderance of bone objects. Bone implements and ornaments of many shapes and sizes, and in various degrees of completion, were found in unexpected numbers; in addition, there were large quantities of mere refuse-bones split to facilitate the extraction of marrow, charred bones, and those apparently tossed carelessly to one side. Among this mass of worked and unworked material there may be recognized skeletal fragments of such animals as the deer, antelope, mountain sheep, bear, and various smaller mammals. There are also a few fragments of heavy antler which appear to be elk and several pieces of large, worked bone that have been tentatively identified as those of the buffalo. All of these, taken together, indicate that the ancient house builders were persistent hunters and that the animals killed not only contributed largely to their food supply, but formed, also, the chief source of one of the materials most essential to the economic pursuits of the community.

Awls are especially numerous and vary in size from the small, sharpened metapodial of the deer to those cut from the full length of the canon bone. Most of them are merely ground and sharpened fragments, but several exhibit a high degree of specialization and are really pleasing examples of aboriginal art. A few were perforated at the butt end for the attachment of a cord and still others, as in plate II, were decorated with incised lines. Some of the awls are long and slender, like needles; others are heavy, blunt, and 
frequently chipped at the end as though employed as punches in flaking arrow points, etc. But all of them, crude and finely worked together, were utilized in the daily activities of their owners, in weaving baskets, in making skin garments, and in numerous lesser tasks for which they were not, perhaps, especially intended.

Closely allied to the bone awls is rather an extensive group of implements shaped from antler. These include chiefly punches and flaking implements, but there is, also, a remarkable collection of wedges, three of which are figured in plate I2. Among the antler fragments, as with the bones, there are specimens that accurately illustrate the manner in which they were prepared for use-specimens which include selected though unworked tynes, those partially or completely sawed with flakes of flint and cut pieces that show various stages in the grinding process by which the objects were brought to completion.

Next to the awls, numerically, is a large series of more or less carefully shaped objects, some of which are shown in plate I3. Most, perhaps all, of these were employed as dice or counters in various games and yet some of them were unquestionably adaptable to other purposes. The series is truly noteworthy, both in point of number and in the workmanship of many of the specimens. These arrange themselves naturally into groups, according to the character of the finished object-groups which range from the rudely chipped counter to those neatly polished, perforated, and ornamented by drilled dots or incised lines. A large percentage of these, crude and highly worked alike, bear traces of red paint on the under or concave side and it may be that each one was so marked when in use. That all of these, especially those which are perforated, were not employed exclusively in games is indicated by the recovery of 10 charred "counters" together with I4 bone pendants-the whole probably forming a necklace-from the ashes of a fireplace in Kiva IV.

Pendants and broken counters reworked to form like ornaments, beads of various sizes, small gaming disks or dice and even finger rings are among the bone objects collected. The latter, especially, will bear brief consideration, since the specimens recovered illustrate each stage in ring manufacture. A section of predetermined width was sawed from a large bone, as indicated in plate II; this piece, in turn, was ground down and polished by rubbing on sandstone and perhaps later carved or incised with lines. The hollow character 
of certain mammal bones probably suggested this use, and primitive delight in personal adornment quickly led to the adoption of the new ornament. Complete specimens were fewer in number than the fragments recovered, but all are highly interesting and most of them speak well for the artistic ability of their makers.

Objects of bone collected by the I9I7 expedition were important both in quantity and in quality of workmanship. The stone artifacts, on the other hand, although numerous, embraced but few types and these exhibit no marked deviation from similar imple-

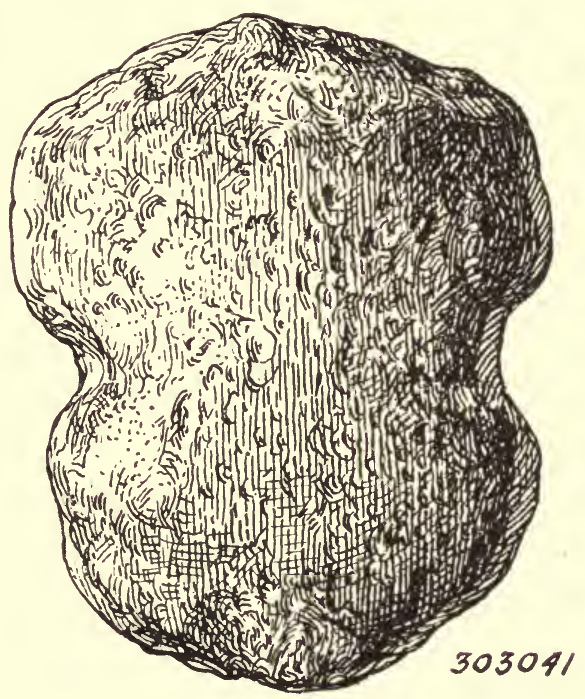

FIG. I.

ments, widely distributed throughout the Southwest. As might be expected, hammer stones and mullers predominate, but there are also large numbers of rubbing and polishing stones, discoidal jar covers, gaming balls, ${ }^{1}$ etc.

Grooved axes and mauls seem to have been wholly unknown to the inhabitants of the adobe dwellings. After three summers' work among the ruins of western Utah the writer has found but one implement, figure $\mathrm{I}$, which even approaches an ax in form and this is a crude basalt hammer, notched for hafting, and probably made

\footnotetext{
${ }^{1}$ Small stone balls, usually encrusted with a softer material, were employed by various southwestern tribes in games for both adults and children. The recent expedition collected 75 of these and, in addition, two specimens of adobe. To one of the latter was still attached a fragment of its original clay covering.
} 
from a fragment of a broken muller. The absence of these common North American implements is, in itself, significant; especially so, since suitable stone was not entirely lacking. It means either that the aborigines had not yet discovered the feasibility of stone axeswhich is almost unbelievable, considering their advancement in other lines-or that they were still content to use other weapons and to employ fire in felling the larger timbers utilized in the construction of their dwellings and associated structures.

Most of the metates, or stones on which corn, etc., was crushed, are of a type peculiar to western Utah. They consist of fairly large basaltic boulders and are generally but little worked, excepting the upper surface. The exceptional feature of these metates is the small, secondary area adjoining the grinding surface and at that end of the stone which would have been elevated while in use. It is usually, though not always, concave, but whether it was designed as a rest for the muller or intended primarily as a container for ground meal is still problematical. It would have answered either purpose, although not absolutely essential to the efficient use of the metate. The small basin does not customarily appear on stone mills found elsewhere.

Traces of red paint on both metates and mullers illustrate the readiness with which primitive man employed his various utensils in the task at hand. Red ochre was collected along the foothills, brought to the village and pulverized for use in bodily adornment and the ornamentation of pottery, etc. The frequency with which paint-covered mullers are found indicates that the quantity of natural pigment employed by the ancient people of Paragonah was not inconsiderable. It is not apparent that they employed special mortars and pestles in the preparation of paints as was done at Zuñi and elsewhere.

The pottery exposed by the expedition of I9I 7 is much the same as that found during the excavations of the two preceding years. A majority of the shards recovered are of plain ware; corrugated vessels were evidently less common than in ruins farther north. These fragments, however, taken with those which bear traces of ornamentation, are sufficient to indicate the development of the ceramic art among these house builders and to establish a cultural affinity between them and the ancient people south and east of the

${ }^{1}$ The writer's atiention has been called to a similar metate discovered on the outskirts of Moab in Grand County, Utah, by Dr. A. V. Kidder of Harvard University. 
Rio Colorado. Decorated jars and ollas were obviously rare, but bowls carrying the customary black decorations over a gray interior wash were plentiful. On these latter are figured many of the geometric patterns common to the northern part of the prehistoric Pueblo area; only one shard has been noted which carries a representation of an animal. However instructive a comparison of the earthenware vessels from the two regions might be it again seems advisable merely to affirm the similarity in design and leave for a future paper detailed consideration of the western Utah pottery.

An examination of these Paragonah fragments discloses one peculiarity of ornamentation which is too often repeated to suggest mere accident. This is the interlineal use of red paint, superficially applied. The black decorations were painted directly upon the kaolin wash and were permanently fixed when the specimen was fired. Some of these, however, especially bowls with encircling bands, were further ornamented with red ochre and this almost without exception was drawn between the black lines some time after the vessel had been removed from the kiln. The red paint, not being permanent, is readily removed by rubbing, but its decorative effect remains unquestioned. Plain-ware bowls and jars and even coiled ollas were sometimes covered on the outside with a thin coat of this same pigment, producing results which, in general appearance, approach the unpainted red ware of the Little Colorado drainage. Judging solely from the shards collected, earthenware vessels decorated with red before firing were extremely rare in the Paragonah region.

Besides the usual objects of bone, stone, and pottery, a number of less common artifacts were recovered from the big mound. Perhaps the most interesting of these is a tubular stone pipe, figured in plate I5. The original, now in the University of Utah Museum, is of agalmatolite, or possibly serpentine. It is of the well-known California type and undoubtedly reached the Parowan Valley through inter-tribal commerce. ${ }^{1}$ The typical Utah pipe-if a type can be determined from incomplete investigations-is of clay and varies between numbers 303 I 77 and 303 I79, plate I5. Short tubular pipes with flaring lips have been found in widely separated localities; clay

${ }^{1}$ That materials and artifacts prized by primitive peoples were frequently transported almost incredible distances is a fact well known to anthropologists. Several dozen beads made from Pacific coast shells (Olivella biplicata, Sby. and Olivella dama, Mawe), were found in the "big mound" and indicate that the difficulties of a foot journey across the Nevada and California deserts were not insurmountable. 
pipes ${ }^{1}$ with bowls inclined upward at the end of the stem, or lying wholly within it, are not uncommon and these, too, are widely distributed throughout the region of the adobe houses. Stone pipes of this same general type, but much heavier than those of clay have been found in other western Utah mounds, although none were discovered by the recent expedition.

Among the lesser antiquities recovered are certain seeds and pieces of basketry-perishable articles whose charred condition is alone responsible for the their present degree of preservation. The first of these includes grass and squash seeds, corn, beans, and piñon nuts-foodstuffs which indicate that the old house builders knew something of agriculture and did not rely wholly upon the skill of their hunters. The basketry, one fragment of which is illustrated in plate 12 , is of the coiled variety so common among the ancient cliff-dwellers and represents a high quality of workmanship. Baskets were unquestionably in constant use by the primitive folk of Parowan Valley and far more numerous than their occasional remains would lead one to believe. ${ }^{2}$

Something has been said above of the use as paint of clay stained with oxide of iron. Pieces of yellow ochre were also found, but these were undoubtedly employed chiefly for bodily adornment. So far as known, potsherds bearing indications of yellow decoration have not yet been discovered in western Utah mounds. Small masses of kaolin are occasionally recovered from these ruins-masses that furnished the whitish coat with which the vessels were surfaced, previous to the application of decorative designs. Some of them, however, are so nicely shaped and of such definite form (pl. I2, a) as to suggest their possible use in certain kiva ceremonies. ${ }^{3}$ A con-

\footnotetext{
${ }^{1}$ The small effigy pipe, number 301976 , plate 15 , is the only one of its kind known to have been found in a Utah mound. The original, now in the University of Utah Museum, is of clay and probably represents a ground squirrel; its stem had been broken one-half inch from the bowl, but was subsequently ground down for continued use.

${ }^{2}$ Rumor has it that pieces of charred cotton cloth have been found during previous excavations at Paragonah, but no traces of such fabric were discovered by the I9I7 party.

${ }^{3}$ A story often repeated at Paragonah relates that the walls in one of the adobe dwellings previously exposed were painted white and, over this, figures in red, green, and yellow had been drawn. The excavation of many similar ruins, both at Paragonah and elsewhere, has failed to disclose any trace of like ornamentation, although walls are frequently observed whose faces are covered with a thin coat of alkaline salts, deposited by the network of rootlets which follow down the hard wall surface and tend to separate it from the softer accumulations of débris and wind-blown earth. In the opinion of the writer,
} 
siderable vein of this material is said to exist in the Escalante Desert, northwest of Rush Lake and about 20 miles west of Paragonah.

Two or three small masses of sulphur were also found among the house remains. None of these, however, bears any mark which would suggest that the mineral had been intended for, or put to, a definite use. It would appear most likely that the original collector had been attracted merely by the color of the stone and carried it to the village under the assumption that it could be ground into paint.

A few fragments of ore-bearing rock were recovered at the same. time. These were utilized solely as hammer-stones and are not, as might be inferred, evidence that the ancient house builders possessed knowledge of smelting processes. Implements and ornaments of metal are entirely unknown among the Utah ruins-persistent local contentions to the contrary-and they have never been discovered in pre-Spanish villages in any other section of the Southwest, excepting, of course, those few southern Arizona and New Mexico localities that had established inter-tribal communication with the peoples of central Mexico. The highly colored stories so widely circulated throughout Utah regarding the discovery of gold, silver, and iron artifacts in purely prehistoric ruins are deliberate fabrications whose chief purpose seems to be the willful deception of the most credulous. Tales of this sort have frequently acted as a spur to those seeking supposed fabulous riches and are directly responsible for the wanton destruction of many aboriginal remains whose historical value cannot be over estimated.

\section{SUMMARY}

Certainly the chief result of the recent Smithsonian InstitutionUniversity of Utah expedition was the successful exposure of some 40 odd houses and numerous associated structures, comprising the greater part of an extensive prehistoric village. These were of entirely distinct types, grouped to form a single compact community ; their apparently studied arrangement and the obvious relationship between them and the nearby, circular rooms is evidence that definite social and religious principles governed the daily life of their occupants. The more permanent dwellings were of adobe, built up usually in courses and smoothed or plastered on the inside; the secondary buildings may be described as brush shelters-the living quarters of the villagers-in which were performed most of their

these salty deposits were mistaken for "whitewash"; the "paintings" may be wholly or in part the product of the imagination. 
domestic activities. The shelters seemingly were erected without serious consideration of their possible interference with the general plan of the village; they were easily constructed and the site chosen for each appears to have been the least obstructed space nearest the home of the prospective builders. Huts of this type, together with the adobe houses, acted as natural barriers that caught and held the wind-blown sand and earth as it swept across the treeless foothills and settled in and among the dwellings, adding materially to the size of the mound. Not all of the exposed dwellings were inhabited simultaneously and it is highly probable that many decades elapsed between the occupation and abandonment of the site.

Ceremonial chambers adjacent to the secular structures suggest that at least three clans had united in the establishment of the village. In form and their obvious connection with the neighboring habitations these circular rooms resemble the kivas in cliff-dwellings and historical Pueblo villages. Although certain structural details commonly identified with the latter are absent in the Paragonah kivas, but little doubt remains that they served similar purposes and exerted equally important influences upon their respective builders.

Large numbers of artifacts were recovered from the refuse heaps which filled the open spaces between the houses. Most of these are of bone and stone, but charred fragments of more perishable materials were also found, and all of them, taken together, indicate that the ancient artisans possessed considerable ingenuity and attained creditable results with their crude implements. Among the objects collected are many shards of earthenware vessels decorated with geometric figures of a type common to prehistoric communities south and east of the Rio Colorado. Inasmuch as decorative motives did not change readily among the ancient house builders of the Southwest this similarity in pottery design is noteworthy.

Not only the character and ornamentation of certain lesser antiquities, but also the structural peculiarities of the rectangular dwellings and their general relationship to each other confirm the opinion that a marked cultural affinity existed between the ancient people of Parowan Valley and those inhabiting the semi-arid regions east of Navaho Mountain. Just how extensive and far-reaching this may be can be determined only by additional investigationsresearches that shall have for their prime motive the tracing of the ancient culture so characteristic of western Utah. Once these limits are ascertained the problem of the Utah mounds will have been solved and the builders of the adobe dwellings will have found their rightful place in the story of our prehistoric Southwest. 


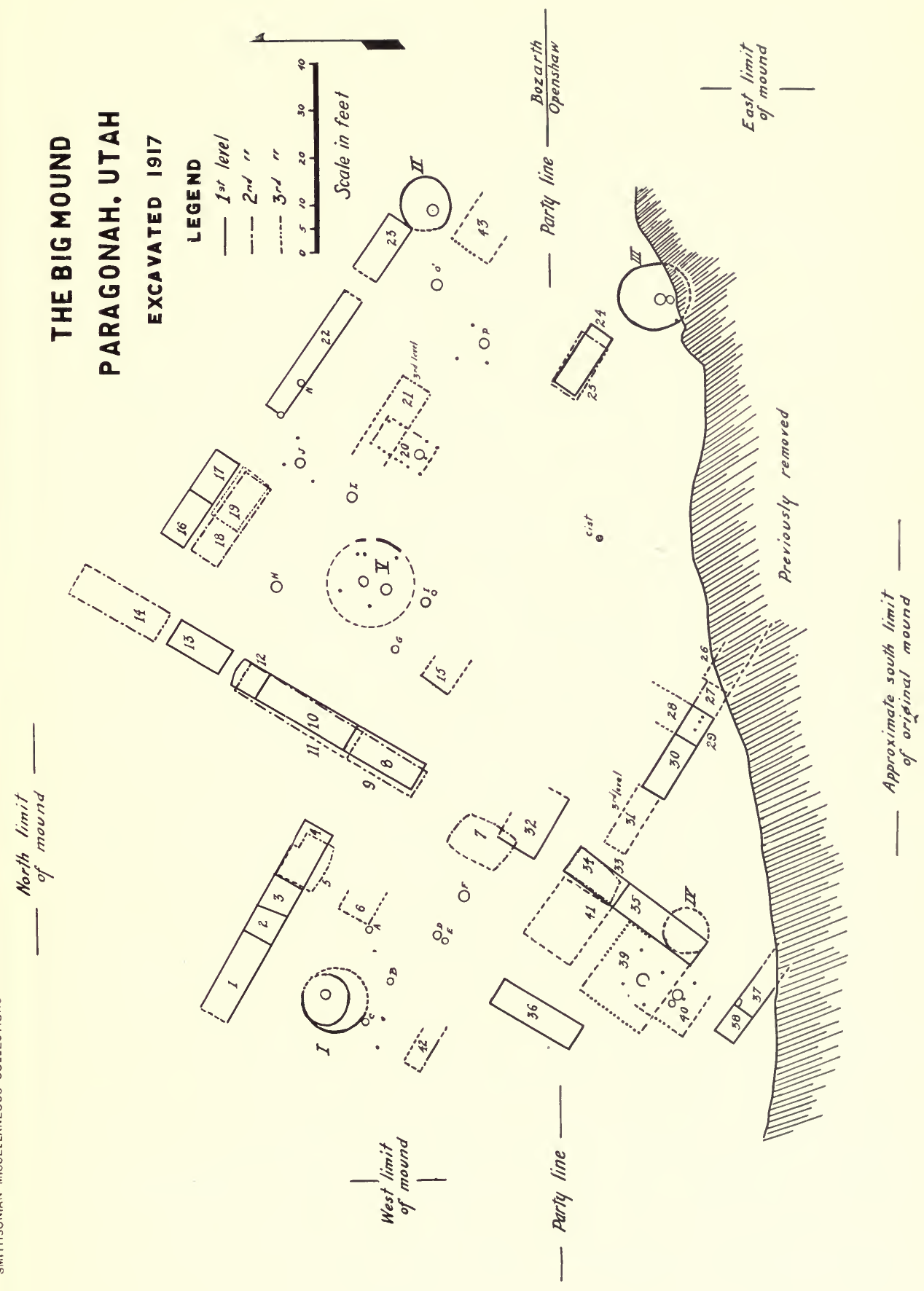




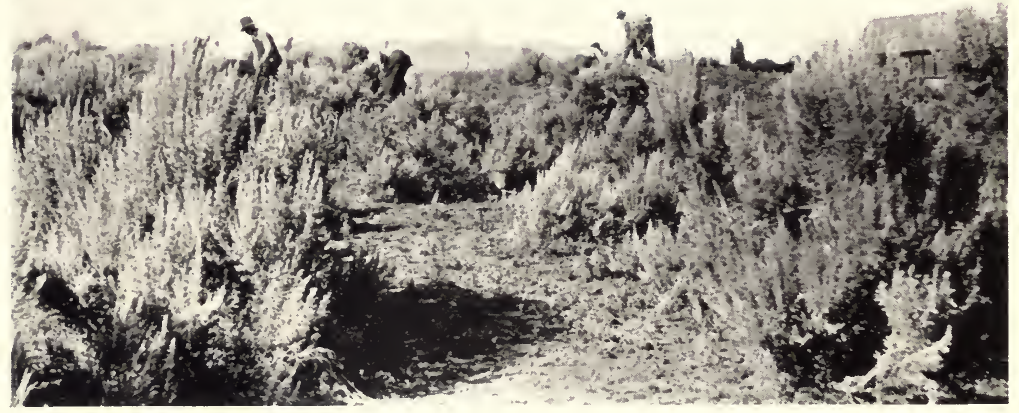

Trenching in search of rooms on the northwest quarter of the mound. View from the north.

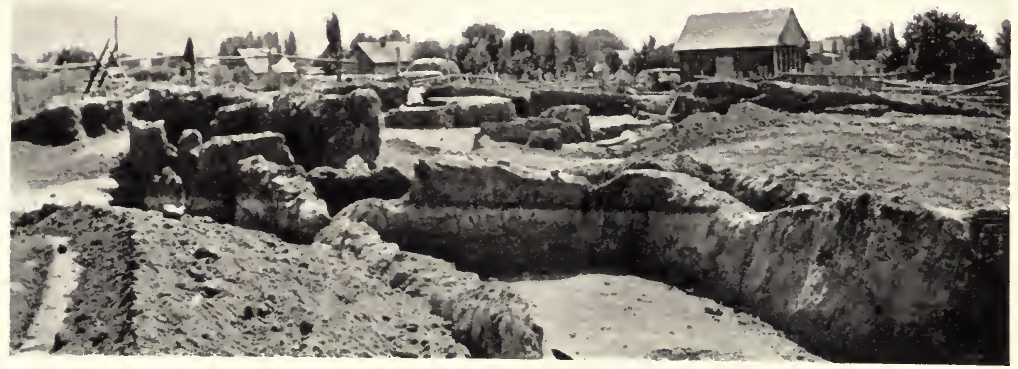

Excavated northwest quarter of the big mound with Room It in the foreground. Compare view above. 


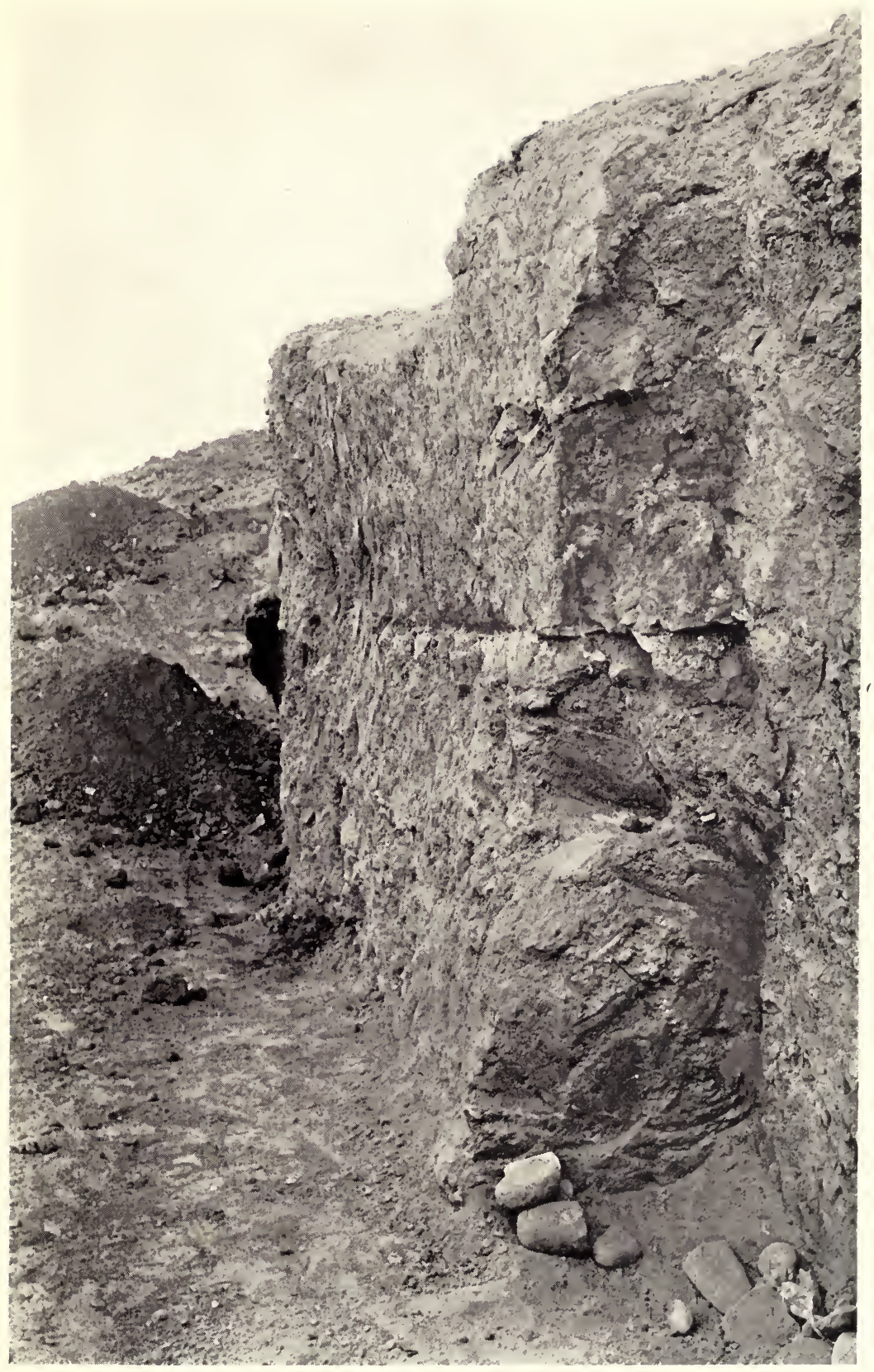

Outer west walls of Rooms 8 and 9, from the southwest. The layer of broken adobe shown in the middle of the photograph rests upon loose earth and débris and forms a foundation for the west wall of Room 9. 


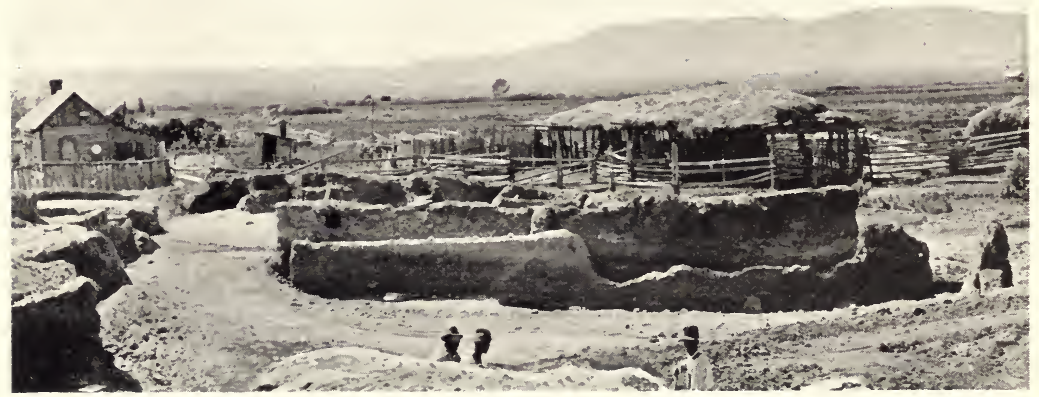

Looking northwest, across Rooms 8-I2. The depth of the court accumulations is indicated by the workmen who are standing near Fireplace I. West Mountains and Little Salt Lake appear in the distance.

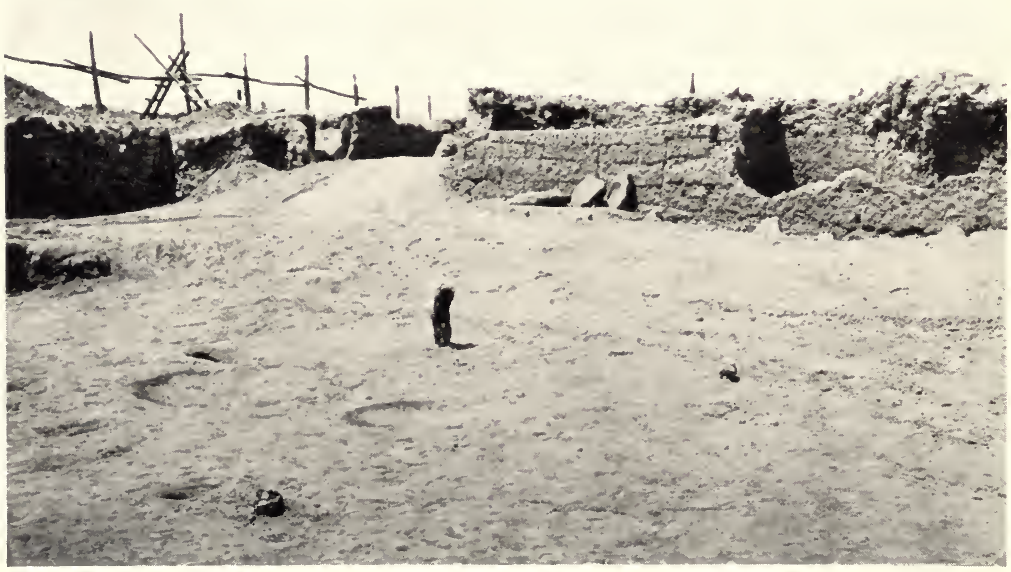

The two fireplaces and three of the charred posts of Kiva $V$, in the foreground. Note the courses in the outer east wall of Room 8. View from the east. 


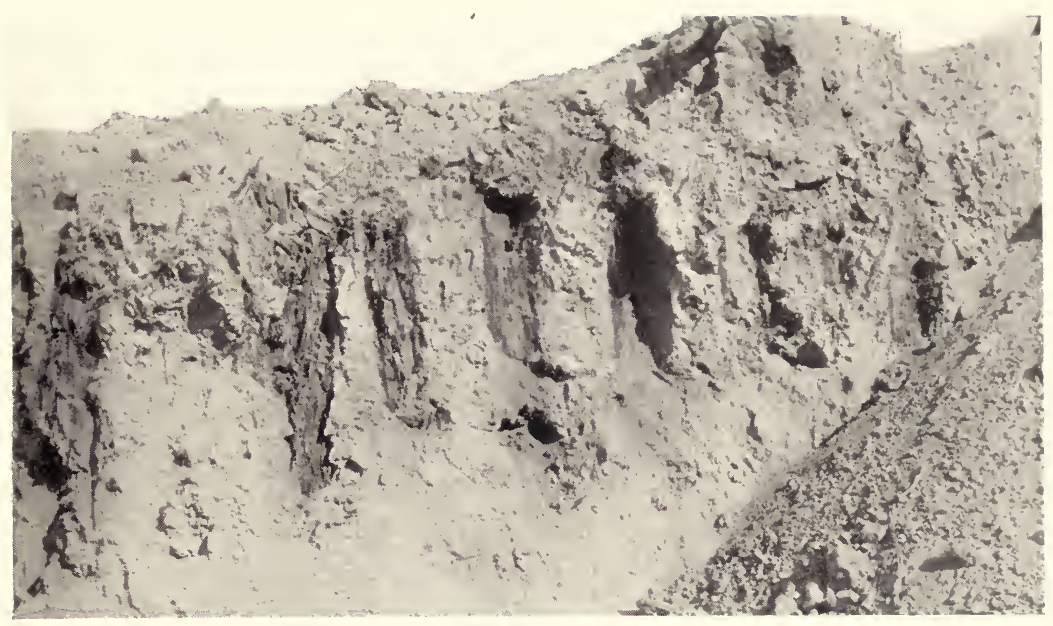

Decayed remains of large upright cedar posts which formed the west wall of Room 43.

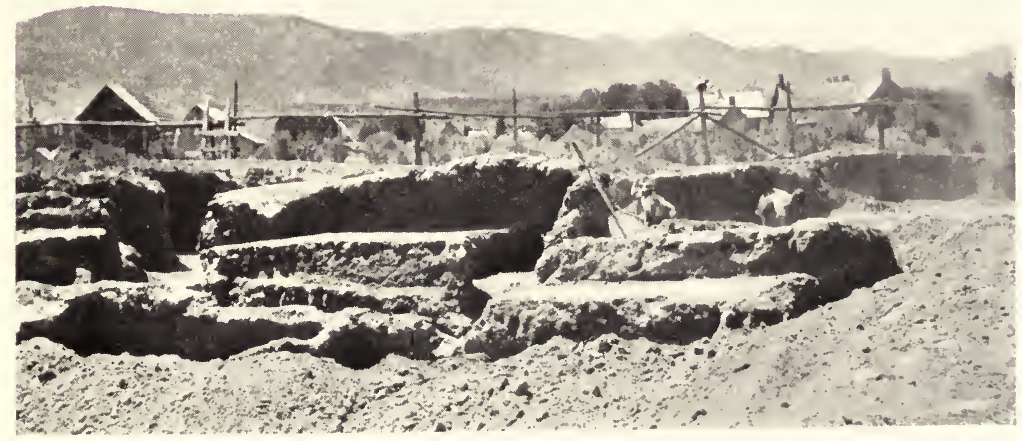

Superposed adobe dwellings, I6-I9, with the floors of Rooms I8 and 19 plainly visible. The men are at work in the central court, near Kiva V. 


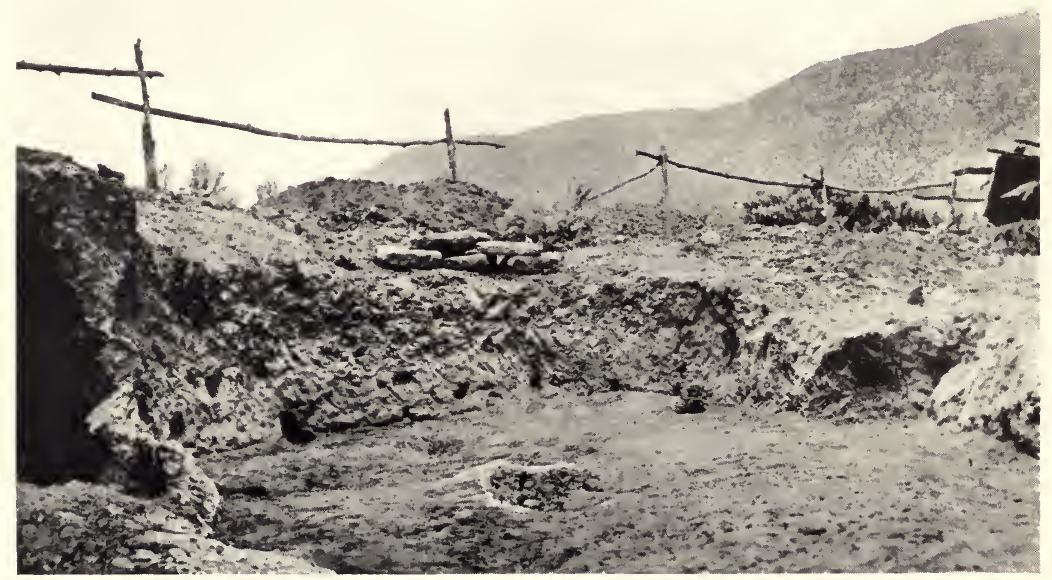

Kiva III from the southwest; the two central fireplaces appear indistinctly in the foreground; numerous squirrel burrows pierce the walls.

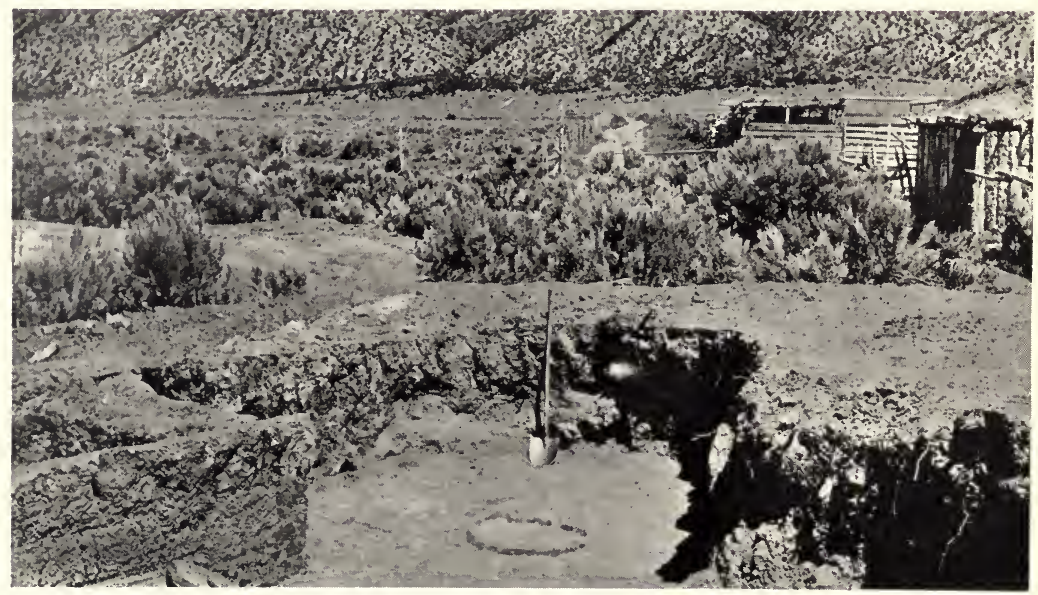

Looking down into Kiva II from above Fireplace $\mathrm{O}^{\prime}$, with Room 23 showing at the left. 


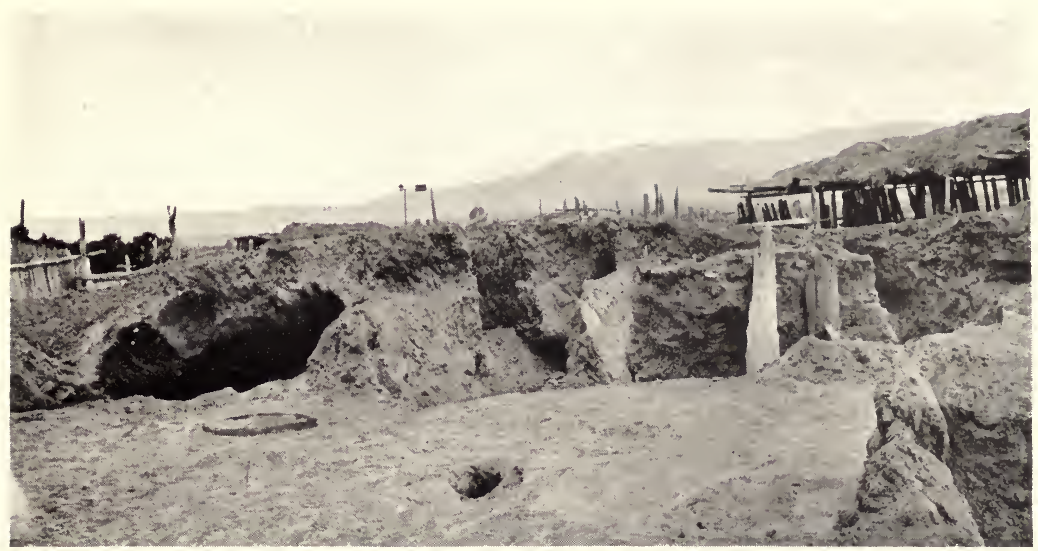

Kiva I from the southwest corner of Room 6, shown at the lower right. The posthole in the middle foreground was the only one found near Fireplace A; Fireplace B appears at the left.

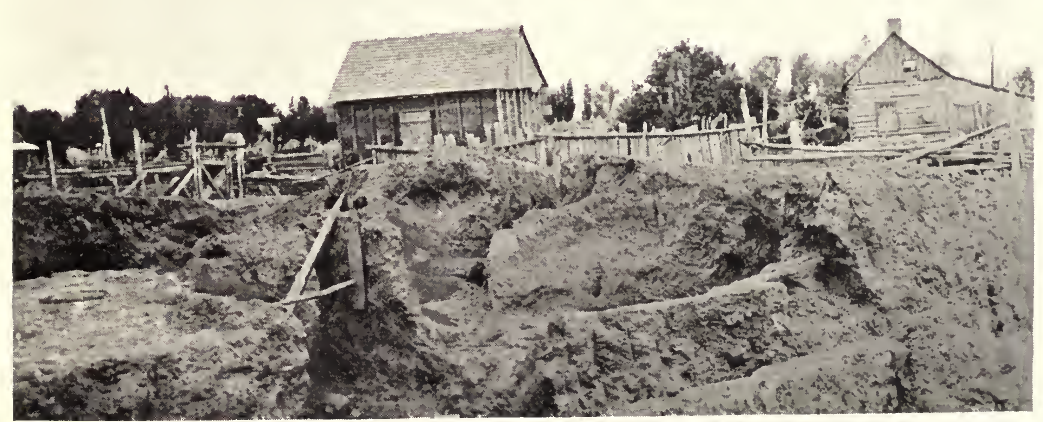

Kiva I from the north wall of Room 2, shown at the lower right; Fireplace $B$ at the left of the braces which support the east wall of the ceremonial room. 


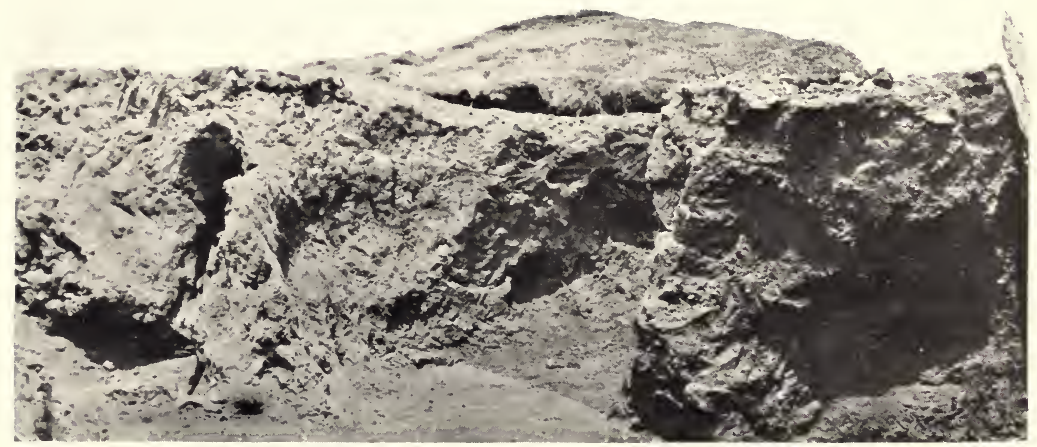

Looking into Kiva I from a point near Fireplace C, but within the standing south wall of the larger ceremonial chamber first constructed. Part of the latter appears at the left.

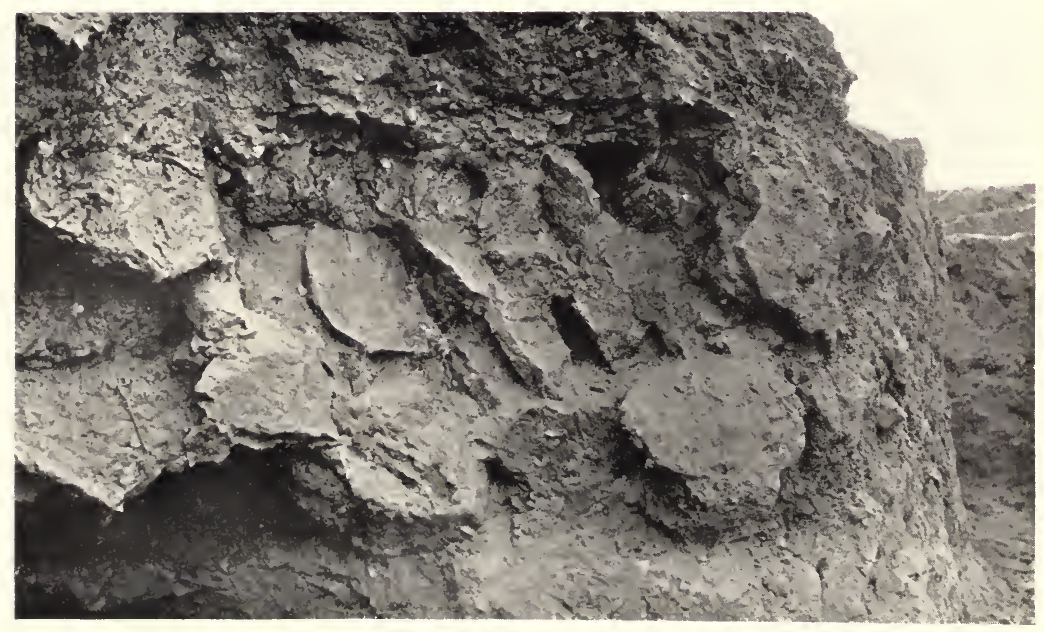

Rounded masses of adobe wall material under the floor of Room I9. It will be noted that these are not all of the same shape or thickness. 


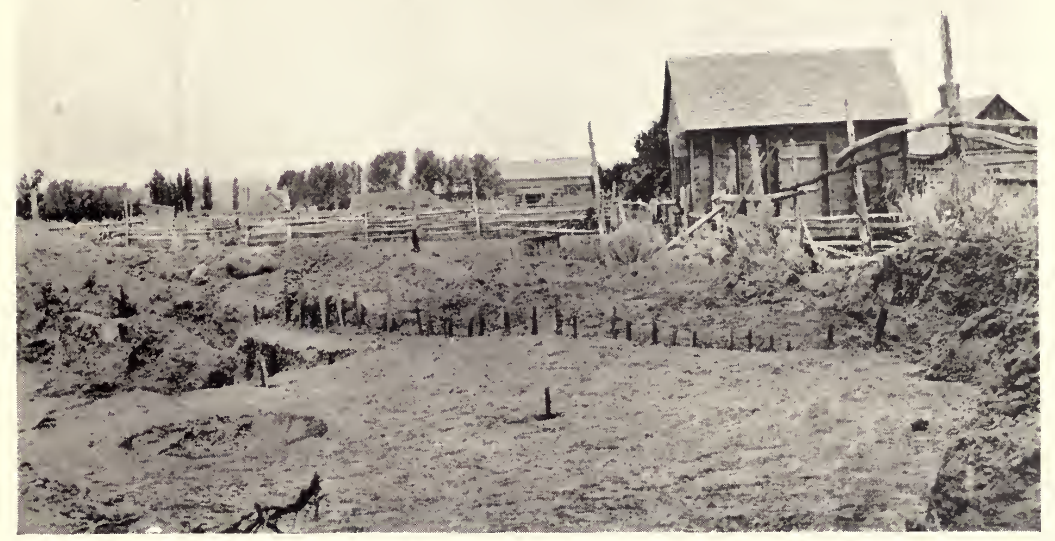

Room 39 from the north wall of Room 35, showing the central fireplace and sticks marking the position of two of the four surrounding pillars. The pegs beyond occupy postholes along the west wall.

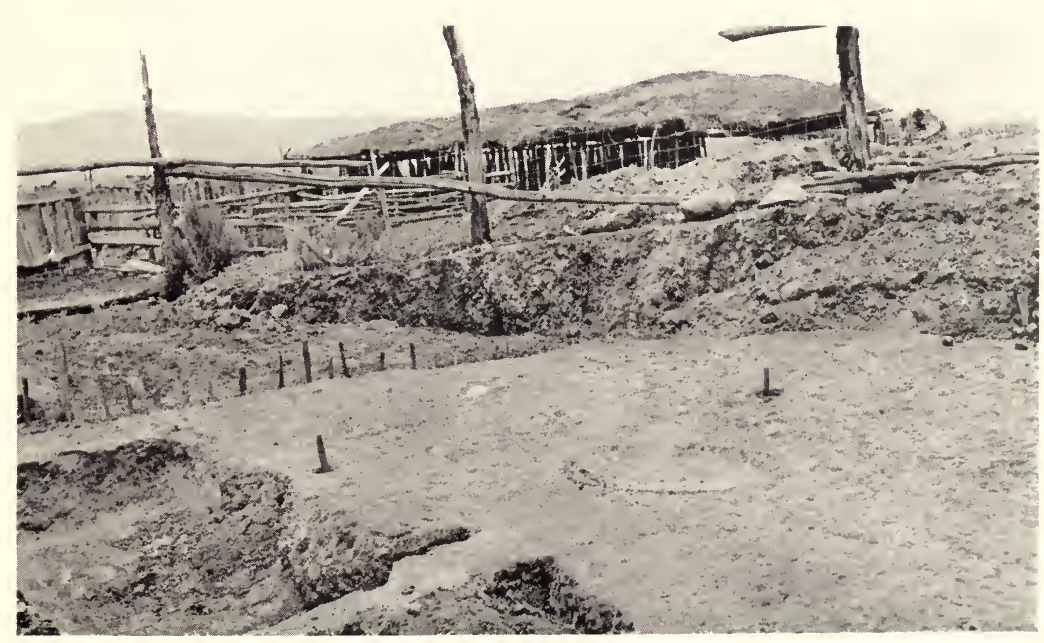

Floor of Room 39, as seen from the south. In the foreground, the wall of an earlier dwelling, razed to the floor level of the later house. Pegs mark the position of upright posts. 


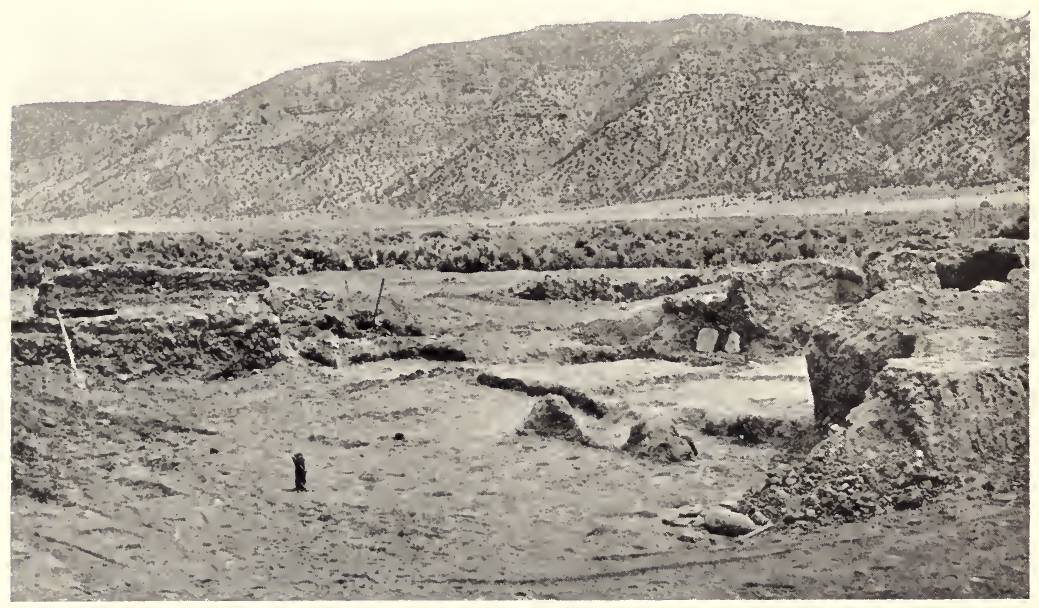

Looking northeast across the central court, from Room I5; wall fragments and charred uprights of Kiva $\mathrm{V}$ in the middle foreground; south wall of Room I9 stands at the left. Various levels of occupancy are indicated.

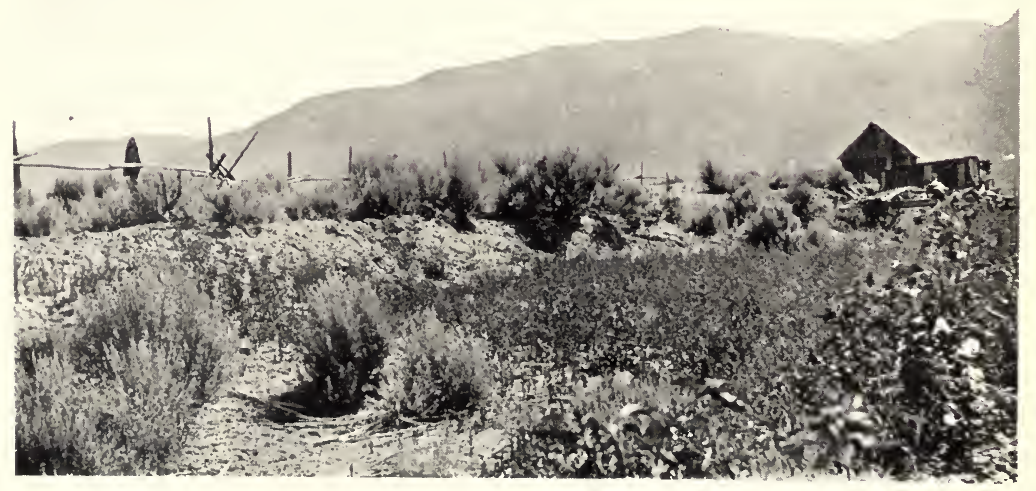

View from the southeast, showing north limit of the excavations which previously reduced the south end of the big mound. 

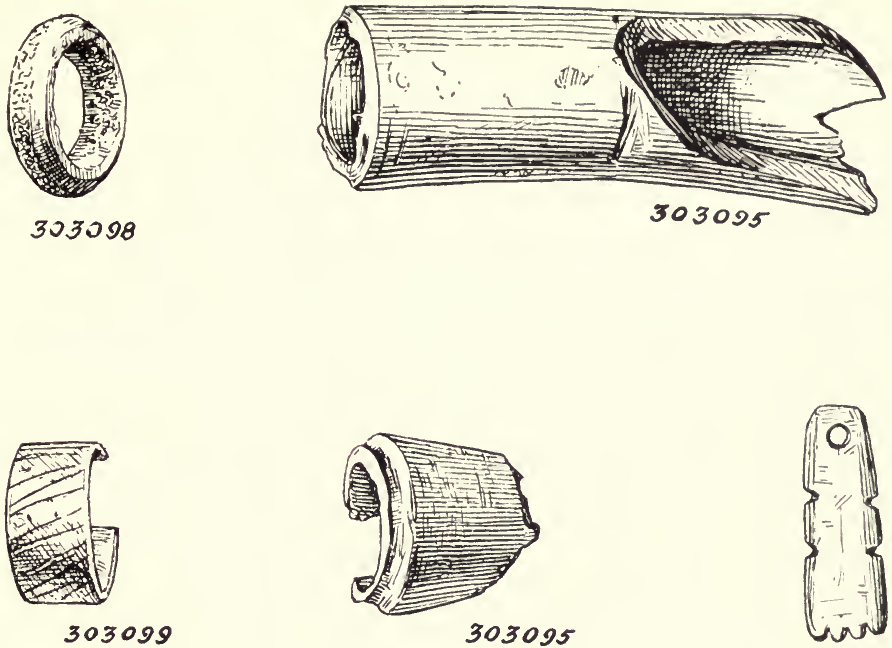

303099

303145
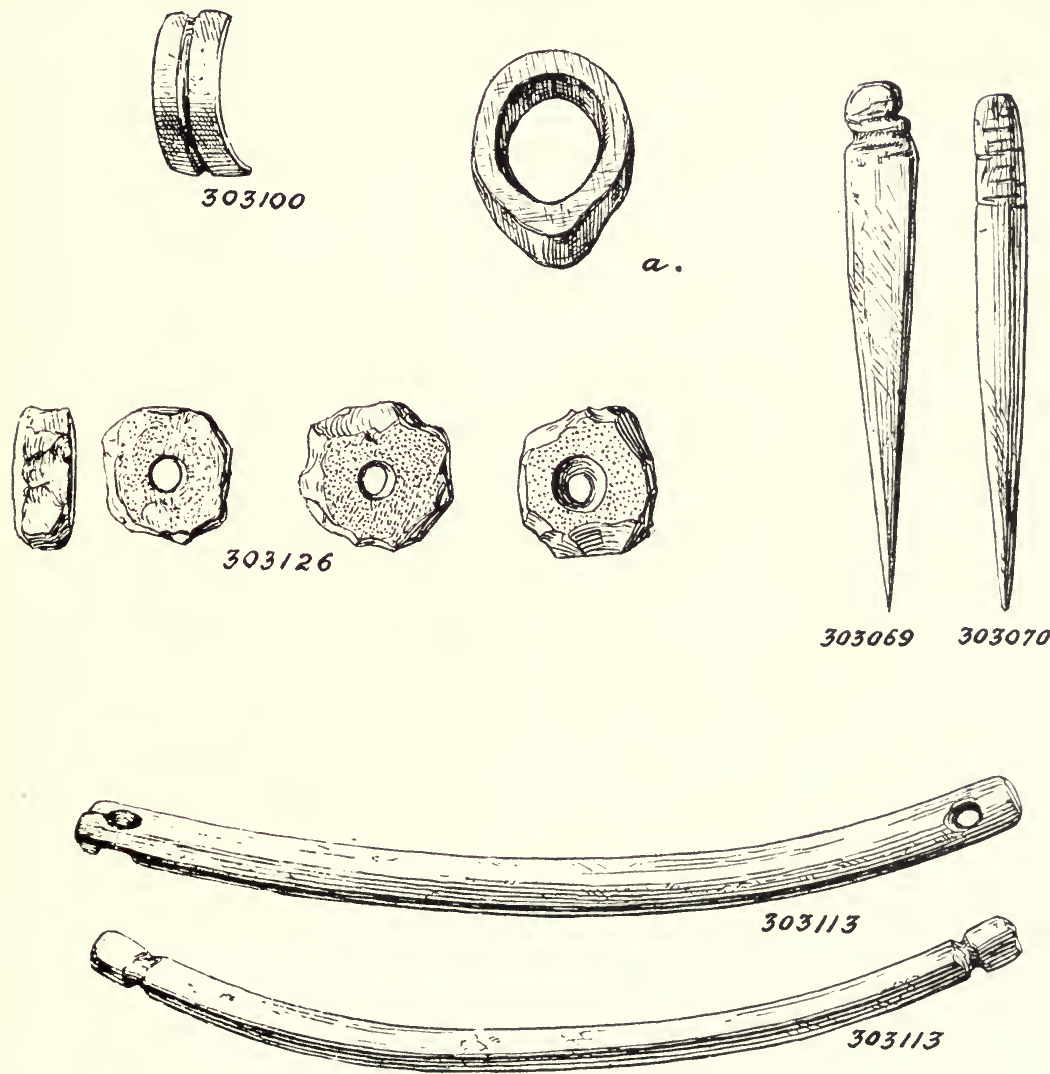

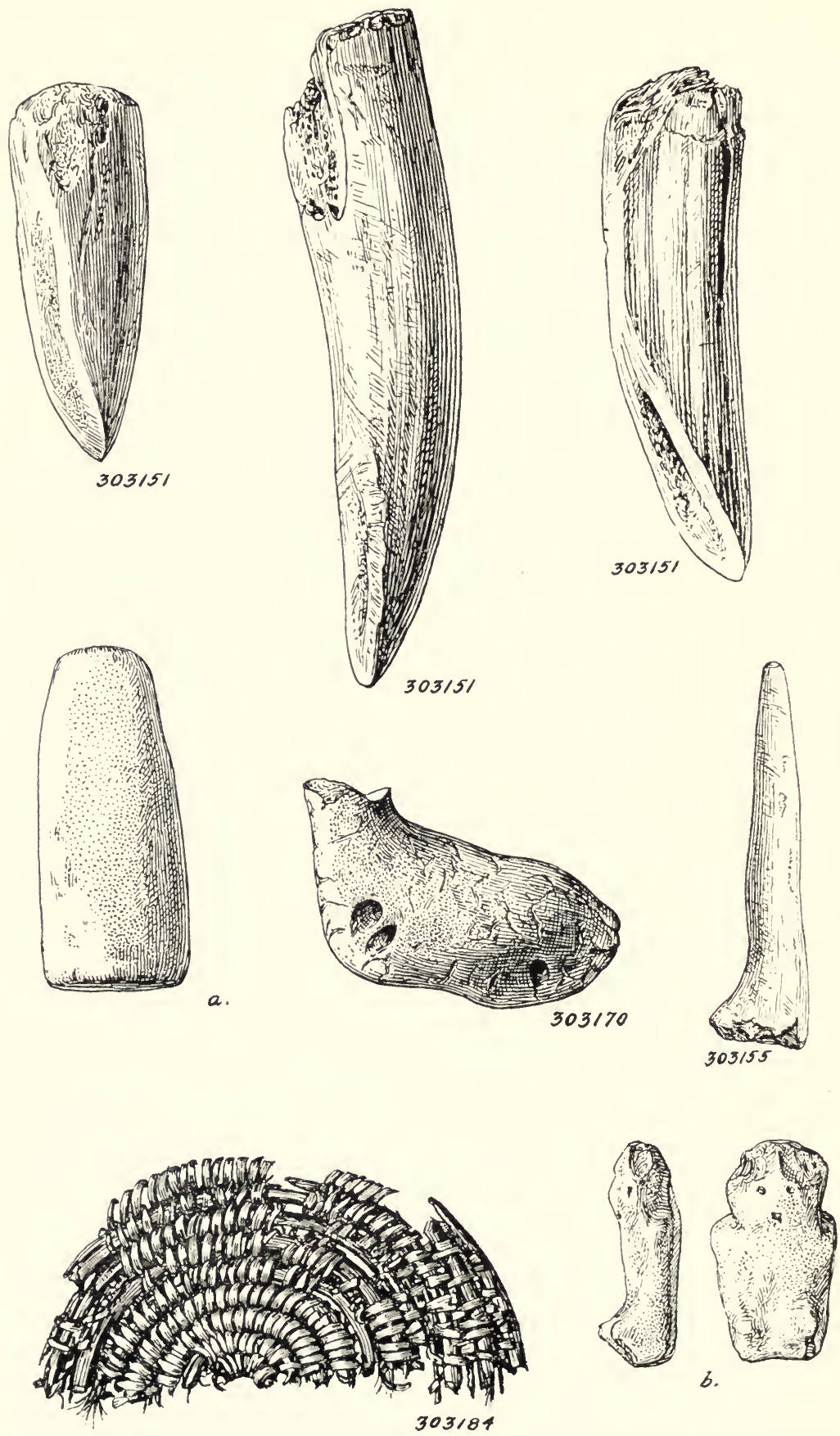

b. 

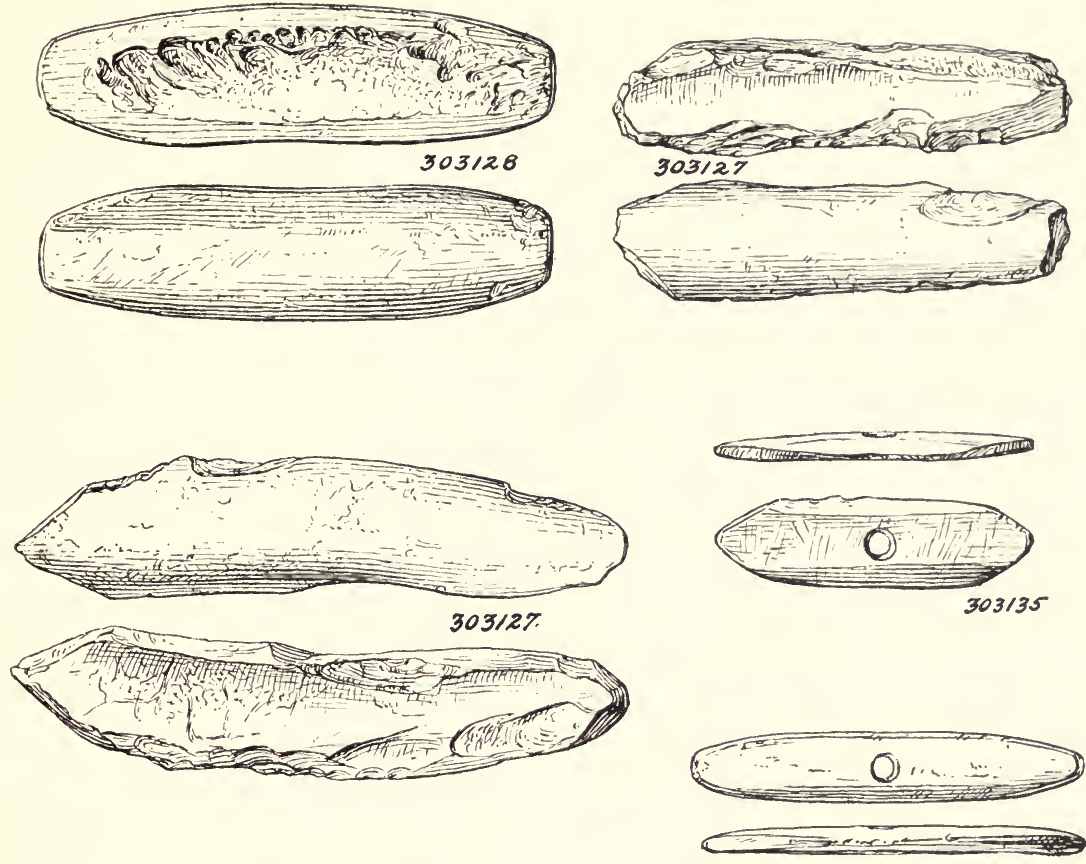

303135

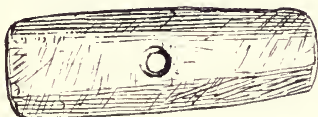

$303 / 30$

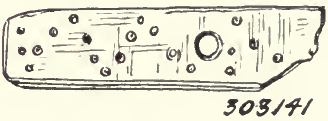

$303 / 30$

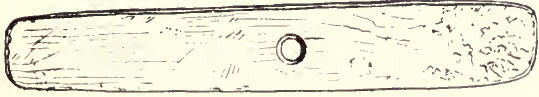

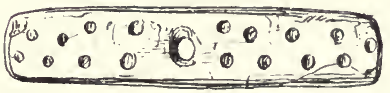

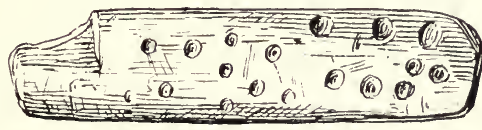

303140

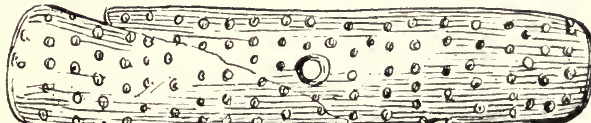

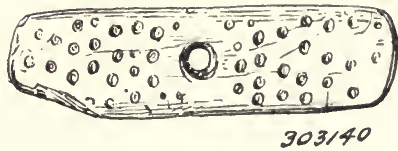

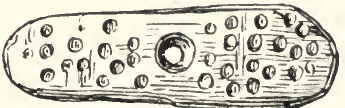



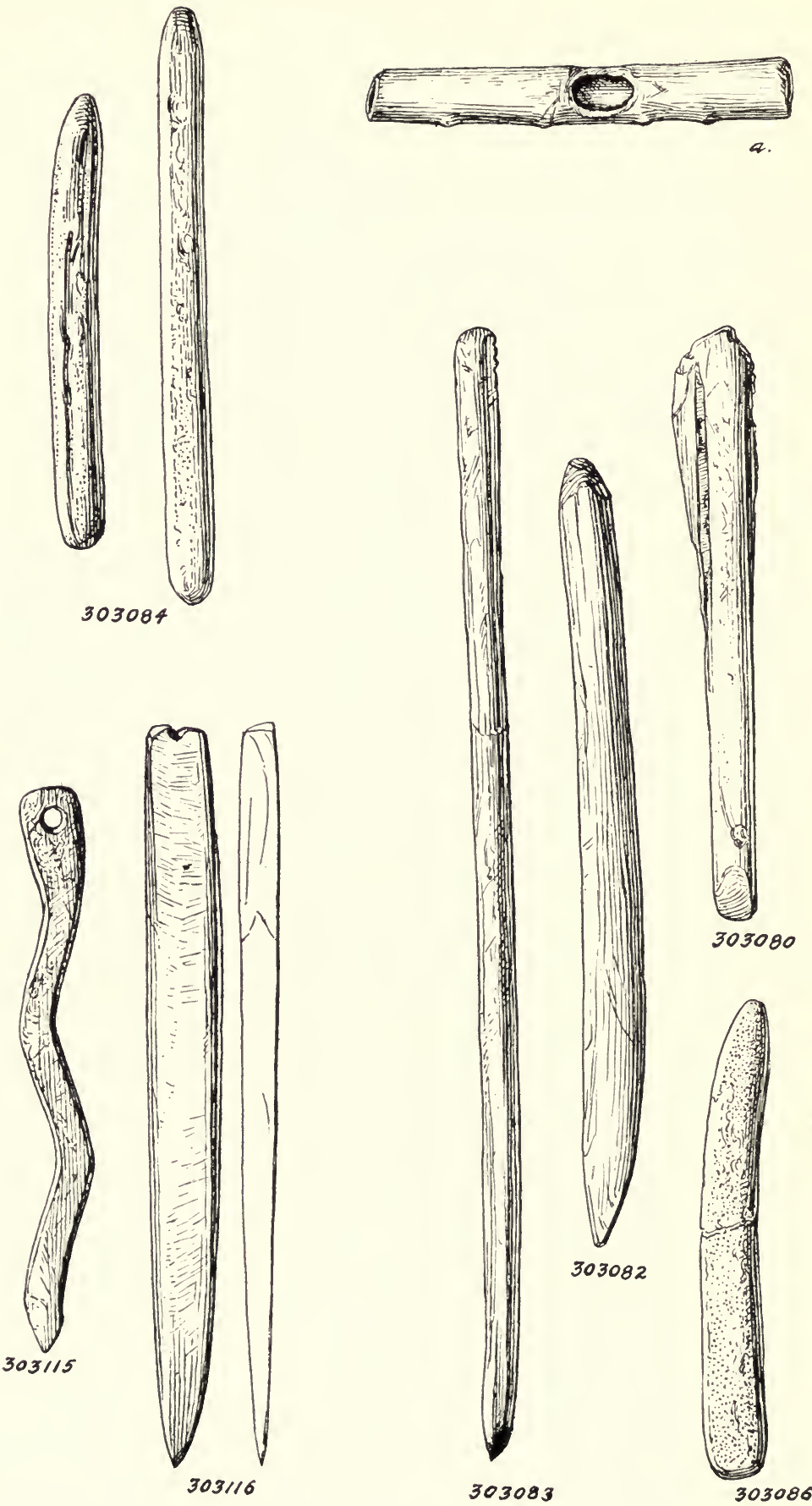

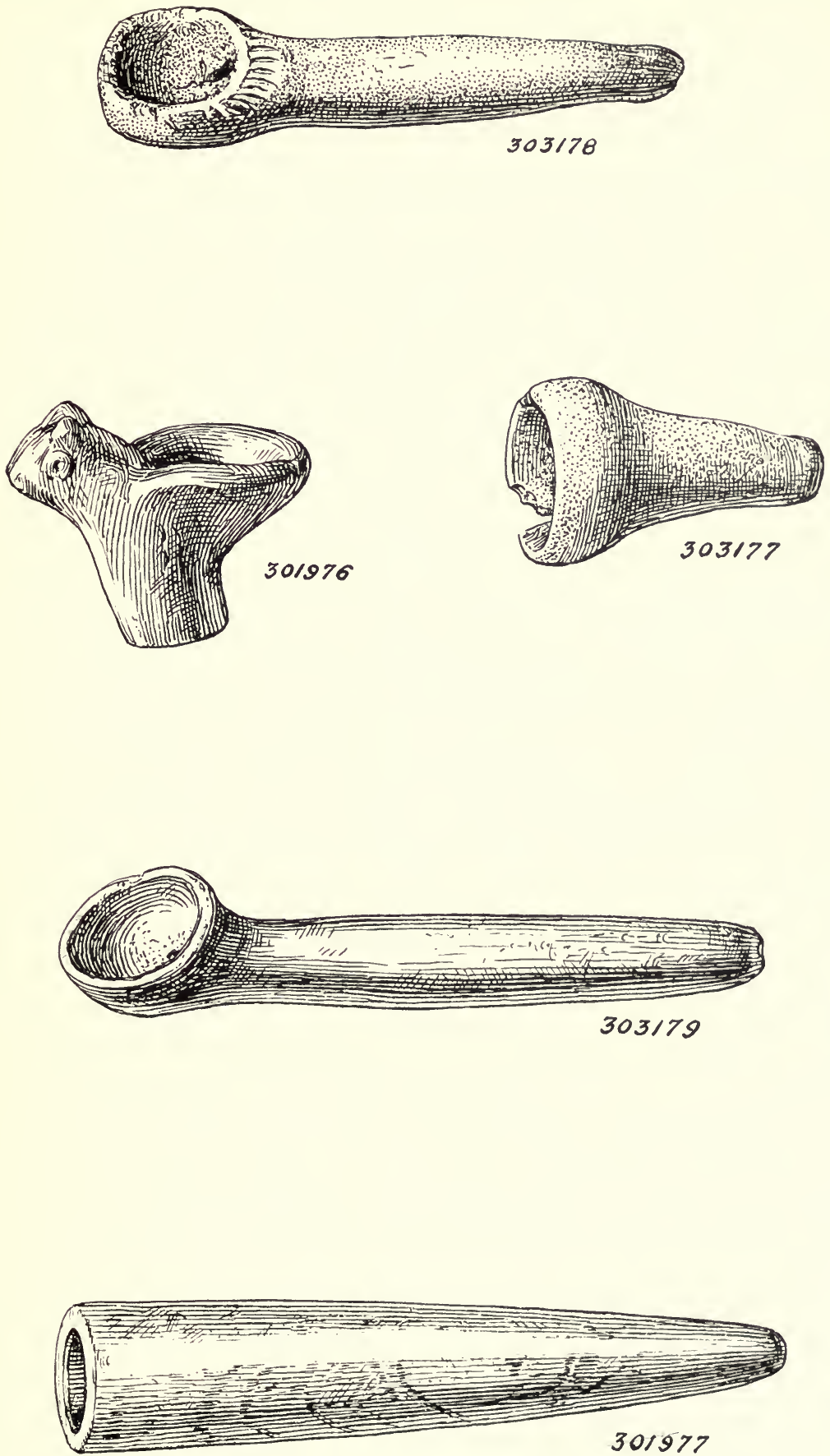




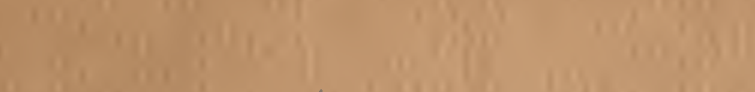

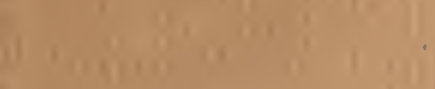

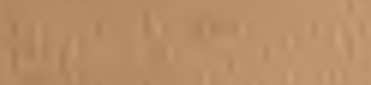

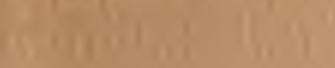

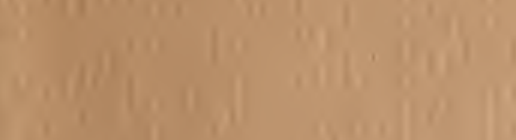

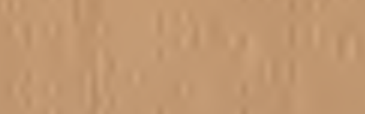

$\left.\log _{11}^{10}\right|^{1} x^{n}$

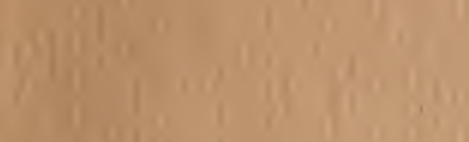

$(1, i)$

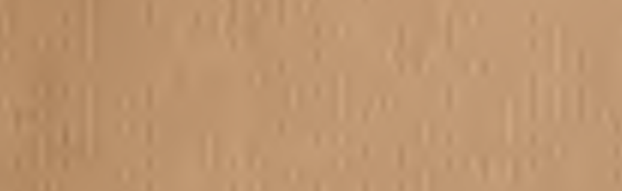

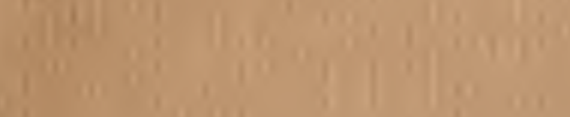

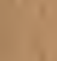

and

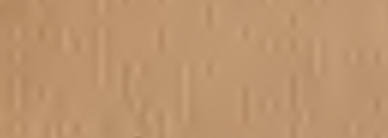

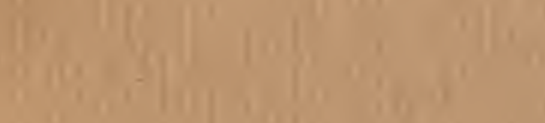

10
11
11 and 5

1)

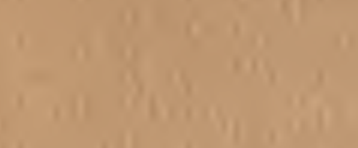

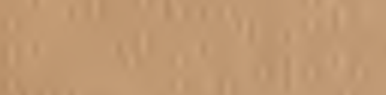

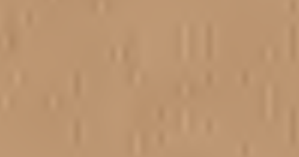

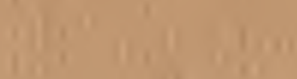

11 


\section{JUN \% $19 \overline{6} 2 \mathrm{DAY}$ USE}

RETURN TO DESK FROM WHICH BORROWED

ANTHROPOLOGY LIBRARY

This publication is due on the LAST DATE stamped below.

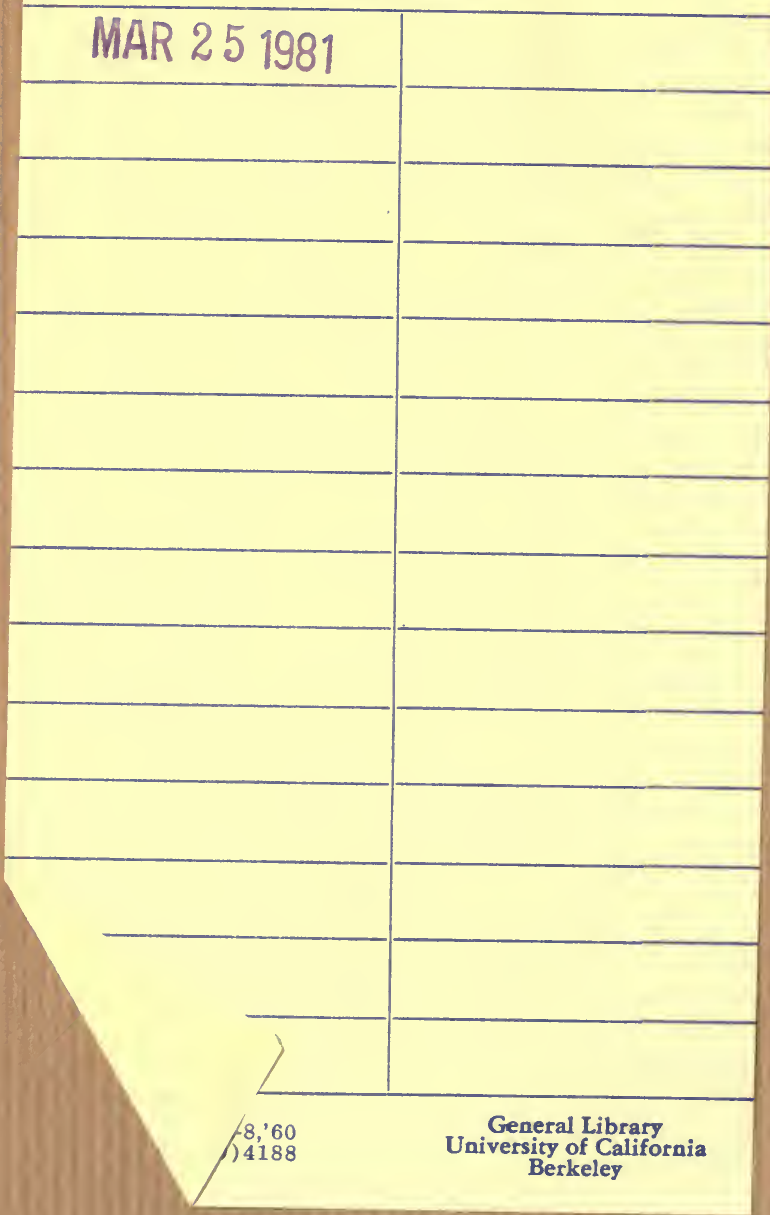


RETURN TO the circulation desk of any University of California Library

or to the

NORTHERN REGIONAL LIBRARY FACILITY Bldg. 400, Richmond Field Station

University of California

Richmond, CA 94804-4698

ALL BOOKS MAY BE RECALLED AFTER 7 DAYS

- 2-month loans may be renewed by calling (510) 642-6753

- 1-year loans may be recharged by bringing books to NRLF

- Renewals and recharges may be made 4 days prior to due date

\section{DUE AS STAMPED BELOW} MAR 062007 


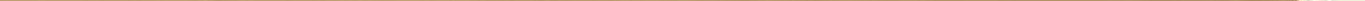

